\title{
Husserl e Wittgenstein leitores de James: a questão do tempo
}

\author{
Denis Perrin \\ Universitté de Grenoble II
}

resumo Este artigo parte da constatação de que a análise jamesiana da consciência do tempo (The Principles of Psychology, XV-XVI) constituiu uma fonte comum fundamental das meditações husserlianas e wittgensteinianas relativas ao tempo, o specious present engendrando tanto o ursprüngliche Zeitfeld de Husserl quanto o fliehendeGegenwart doWittgenstein de 1929. Em seguida, examino a possibilidade de apreender a articulação entre as concepções do tempo de Husserl e de Wittgenstein no nível de suas respectivas apropriações da análise de James. Respondendo de modo afirmativo, sustento de início que essas apropriações se cruzam na crítica do presentismo jamesiano ("Apenas o presente é real") e da idéia segundo a qual a lembrança é uma imagem-cópia presente. Sustento, em seguida, que o anti-psicologismo dá lugar, no entanto, a desenvolvimentos muito diferentes em Husserl e em Wittgenstein. Aquele, com efeito, visa purificar o "núcleo fenomenológico" contido na análise jamesiana de seus resíduos psicológicos para revelar o que ele nos ensina acerca dos modos de aparecer temporais essenciais. De modo inteiramente diferente, Wittgenstein irá pôr em questão a própria imagem do fluxo do presente de consciência, ao descrever a genealogia dessa imagem a partir de erros acerca da linguagem ordinária. $O$ resultado desseartigo é duplo: de um lado, se a análise jamesiana é realmente uma fonte comum às reflexões husserliana e wittgensteiniana acerca do tempo, no final das contas ela dá lugar a apropriações quase opostas; de outro, o debate James-Husserl-Witt genstein permite confrontar as abordagens psicológica, fenomenológica e gramatical do tempo, e, dessemodo, em particular, especificar esta última.

palavras-chave James - Husserl - Wittgenstein - tempo - fenomenologia

Publicado originariamente em Alter, $\mathrm{n}^{\mathrm{o}} 11$; agradecemos à revista Alter a permissão da publicação dessa tradução (nota do ed.). Tradução: Bento de Almeida Prado Neto. 


\section{0}

\section{Introdução}

Este estudo teve sua origem em duas constatações que eu gostaria de começar por registrar. A primeira consistiu, de início, em observar a existência de pontos de convergência importantes entre as filosofias de Husserl e de Wittgenstein acerca da questão do tempo, em particular quando esses dois autores desenvolvem sua crítica da análise psicológica da consciência do tempo. No entanto, a fenomenologia husserliana revelou-se pertencer justamente ao tipo de reflexão sobre o tempo visada por Wittgenstein nas reflexões que ele consagra a essa questão. Constatação problemática, portanto. A segunda constatação foi a descoberta, em Wittgenstein, de uma verdadeira meditação do tempo, e a descoberta de que essa meditação foi inspirada em grande parte pela análise da "percepção do tempo" apresentada por James no capítulo XV de seus Principles of Psychology. Ora, como ocorre que a fenomenologia husserliana da consciência do tempo deve muito, ela própria, a essa análise, pôs-se então a questão das respectivas apropriações da análise jamesiana por Husserl e por Wittgenstein, na esperança de que a elucidação dessa questão permitisse esclarecer a primeira constatação. Por essas razões, parece-me interessante abrir um novo capítulo do diálogo Husserl-Wittgenstein, que alguns se dedicam a construir já há alguns anos.

O que está em jogo? Em primeiro lugar, trata-se de trazer à luz um aspecto da obra de Wittgenstein, uma vez que suas observações relativas ao tempo nunca foram objeto de um estudo aprofundado. $\mathrm{O}$ debate a partir do qual Wittgenstein engaja sua reflexão sobre o tempo e a singularidade de sua posição ainda estão por estabelecer. Em segundo lugar, trata-se da própria pertinência do projeto filosófico de uma descrição da consciência do tempo, pois Husserl foi um dos mais eminentes pensadores desse projeto e Wittgenstein, como veremos, um dos seus mais virulentos críticos. Por fim, esse diálogo deveria permitir avaliar de forma um pouco mais precisa a importância e a diversidade da herança jamesiana no seio do pensamento filosófico do século $\mathrm{XX}$.

Proponho-me a tratar esse novo capítulo do diálogo HusserlWittgenstein do seguinte modo. (1) Começarei por destacar o papel que a fonte jamesiana desempenhou na elaboração dos pensamentos husserliano e wittgensteiniano do tempo. (2) Em seguida, irei delinear a crítica comum endereçada por Husserl e Wittgenstein à análise psicológica empírica da consciência do tempo. (3) Mostrarei, por fim, que essa críti- 
ca comum recobre, na verdade, uma radical divergência entre Husserl e Wittgenstein no que diz respeito ao valor que deve ser concedido à descrição jamesiana da consciência do tempo.

\section{I - James, The Principles of Psychology, capítulos IX \& XV: fonte comumdos pensamentos do tempo de Husserl $\mathrm{e}$ Wittgenstein}

\section{Husserl e o alargamento temporal da intuição}

Ainda que a questão de seu conteúdo filosófico preciso ainda esteja em discussão, a influência decisiva das análises desenvolvidas por James nos seus Principles of Psychology sobre a fenomenologia husserliana está doravante solidamente estabelecida ${ }^{2}$. Sabe-se como foi importante para Husserl a empresa descritiva que se realiza na psicologia de James. Gostaria de ressaltar aqui essa influência relativamente às análises fenomenológicas do tempo. O próprio Husserl nos informa a esse respeito em uma nota colocada no início do manuscrito do primeiro capítulo do curso que ele ministrou em Göttingen durante o semestre de inverno 1904-1905. Ele fala, nesse texto "de James, que [ele] estuda ainda e [do qual] recebeu forte impulsão"3. Além dessa confissão, um certo número de análises - e não das menos importantes - desenvolvidas nas Vorlesungen zur Phänomenologie des inneres Zeitbewusstseins (Lições) deixam transparecer claramente a influência de James sobre o pensamento husserliano acerca do tempo. Sem pretender a exaustividade, podemos sublinhar alguns elementos particularmente importantes dessa filiação ${ }^{4}$.

(l) É preciso primeiro notar a similaridade dos níveis nos quais se embrenham a descrição psicológica do "stream of thought", de um lado, e, de outro, a descrição fenomenológica do "fluxo constitutivo do tempo" (zeitkonstituierende Fluss). Nas Lições, Husserl elabora o projeto de uma fenomenologia 5 que a redução não reconduz apenas à aparição na qual se constitui o aparecente, mas aos fenômenos constitutivos da própria aparição. Mais precisamente, Husserl considera a camada hylética como o nível de investigação privilegiado para voltar para aquém do "plano da temporalidade constituída" (HUSSERL, 1950, § 85, p. 289)6 e assistir à constituição da temporalidade imanente. Essa temporalidade imanente é a dos vividos em geral: se a camada hylética não tem a exclusividade da constituição imanente, apresenta no entanto a vantagem de desviar o olhar de todo objeto constituído. Com efeito, para que a consti- 


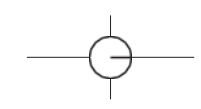

\section{2}

tuição dos próprios atos intencionais possa aparecer para o fenomenólogo, é necessário considerá-los como "sensações" ou "impressões" (o que não deve ser confundido com os "conteúdos primários" que são distinguidos da "intencionalidade" pelas Ideen), isto é, considerá-los unicamente segundo sua pertença ao "campo temporal originário"7 e sua constituição no seio desse campo. Se o fluxo absoluto constitutivo opera "já"8 no nível dos conteúdos primários, é preciso acrescentar imediatamente: "Num certo sentido, portanto, temos consciência de todos os vividos por meio de impressões, eles são todos impressos (...) É na consciência originária que se constituem todas as impressões, tanto os conteúdos primários quanto os vividos que são 'consciência de"' (HUSSERL, 1964, § 42, p. 115 116; grifo meu) ${ }^{9}$. E é nesse sentido de "impressão" e de "sensação" que se deve compreender o "temporal sentido" e "o Datum de tempo absoluto sentido"10 que a fenomenologia das Lições quer submeter à sua descrição. A problemática "funcional" noético-noemática desenvolvida nas Ideen I11 supõe portanto, na verdade, o "absoluto definitivo e verdadeiro"12 da constituição do tempo ${ }^{13}$.

Assim, o esquema de constituição hylemórfica "apreensão-conteúdo de apreensão (Aufassung - Aufassungsinhalt)" que opera no nível da "fenomenologia funcional" não pode bastar à fenomenologia das Lições 14 . Ele vem ser substituído, no nível da constituição absoluta, pela "intencionalidade específica"15 da retenção, ainda dissimulada para o olhar fenomenológico do nível provisório. Esse aprofundamento da investigação fenomenológica, essa "descida nas profundezas da última consciência que constitui toda temporalidade do vivido" (HUSSERL, 1950, $§ 85$, p. 288), redunda notadamente em abandonar o ponto de vista ingênuo adotado pelo sensualismo acerca dos conteúdos primários ${ }^{16}$. Com efeito, o próprio da fenomenológica hylética das Lições é de não mais “construir a vida da consciência por meio de data [em particular hyléticos] como se fossem objetos por assim dizer acabados" (HUSSERL, 1957, § 107 c) 17 - coisa que ainda fazem as Ideen I - mas descrever o modo de constituição desses próprios data,o que requer, antes de tudo, a descrição da constituição da temporalidade imanente ${ }^{18}$.

Ora, é também em um nível impressional que se embrenha a descrição psicológica jamesiana do "stream of thought", isto é, segundo uma consideração da experiência liberta de toda forma prévia que seja enxertada no conteúdo da experiência, e também indiferente à "função cognitiva" dos elementos que compõem "a corrente da sensação elementar (elementary feeling)"19. Sob a figura do "stream of thought", o fluxo da experiência é, 
nesse sentido, desde os Principles,o fluxo da "pura experiência" tematizada pelo empirismo radical.

Cabe, no entanto, fazer duas restrições com relação a essa idéia de um fluxo impressional primário da experiência que seria compartilhada por James e Husserl. De um lado, à diferença de James, Husserl não pensa nunca a "hyle" de forma inteiramente independente da "morphé" destinada a dar-lhe forma - e isso nas próprias Lições ${ }^{20}$ : a matéria sensual define-se ao se distinguir do ato intencional. Em última análise, ela ganha seu sentido no seio do esquema hylemórfico. De outro lado, James não identifica o fluxo da vida subjetiva ("stream of thought") com o do tempo (“time's flow”), mas contenta-se em operar uma gênese psicológica do sentimento do tempo apoiada na concepção dinâmica da consciência como fluxo ${ }^{21}$. De seu lado, Husserl efetua um passo suplementar ao descobrir na própria fluência da consciência, em seu escoamento e seus modos (os "modos de escoamento"22, i.e. as "formações primitivas da consciência do tempo"23), os fenômenos constitutivos do tempo.

(2) A esse nível específico da investigação levada a cabo pelas Lições que irmana esse texto, bem mais que outros de Husserl, às análises dos Principles, vem acrescentar-se uma tese jamesiana que Husserl julgou suficientemente importante para sua própria reflexão para dar uma quasecitação dela no início de seu curso:"Sucessão de sensações e sensação da sucessão não são a mesma coisa" (HUSSERL, , 1964, § 3, p. 21)24. Do ponto de vista da análise husserliana da consciência do tempo, essa afirmação de James representa uma verdadeira abertura descritiva cujo resultado é trazer à luz "um fato suplementar que necessita uma elucidação que lhe seja específica" (JAMES, 1981, XV, p. 591)25. Com efeito, notar que a consciência poderia muito bem consistir numa sucessão incessante de estados sem por isso perceber essa sucessão equivale a notar esta particularidade do presente de consciência de ser dotado de uma certa duração. Assim, desde o início do capítulo XV, a descrição psicológica jamesiana, em razão de uma maior atenção aos fenômenos mentais, rompe com a concepção do presente como um ponto sem extensão: o "presente estrito" sem espessura temporal é afastado na qualidade de uma "abstração ideal" cuja existência "não pode nunca ser um fato de nossa experiência imediata” (JAMES, 1981, XV, p. 571). Por querer vincular a descrição psicológica exclusivamente ao dado efetivo, James doravante consagra sua análise ao "presente sensível (sensible present)", isto é, portanto, ao "specious present". James opera assim um alargamento temporal da intuição: uma vez que se deve supor uma certa duração do presente de 


\section{4}

consciência a fim de que uma sucessão qualquer de acontecimentos objetivos possa ser percebida como uma sucessão26, cabe considerar (por exemplo) que o acontecimento $A$ recém-passado, que no seio da sucessão de $B$ para $A$ precede o acontecimento $B$ estritamente presente, seja ele próprio objeto de intuição, sem o que a própria sucessão não seria nunca percebida ${ }^{27}$. A exatidão da descrição exige portanto que se fale de um "immediately-intuited past"28. Graças a essa "descoberta", James dispõe dos meios necessários para dar conta, no nível descritivo, da "percepção do tempo", isto é, antes de tudo, de uma experiência originária do passado que confere seu sentido ao termo "passado" e da qual é derivada a temporalidade em geral 29 . O "specious present" preenche assim, na análise de James, a função do "modelo original e [do] protótipo de toda espécie de tempo concebido (conceived)" (JAMES, 1981, p. 594), a começar pelo tempo dos historiadores ${ }^{30}$.

Husserl abraça essa abertura descritiva ${ }^{31}$ ao efetuar, por sua vez, o alargamento temporal da intuição que a estende ao recém-passado, consciente na lembrança primária (a "retenção"), e ao fazer desse alargamento uma condição essencial da compreensão fenomenológica da consciência do tempo:"Pois é apenas na lembrança primária que vemoso passado, é apenas nela que se constitui o passado, e isso não de forma representativa, mas, pelo contrário, apresentativa" (HUSSERL, 1964, § 17, p. 58). Além disso, e no prolongamento de James, é pelo fato de que o recém-passado se mantém (segundo modalidades a serem precisadas) no "campo temporal originário"32 (das originäre Zeitfeld) - que evidentemente não deixa de lembrar o "specious present" 33 - que uma consciência do tempo é possível.

(3) Em conseqüência, Husserl é levado a fazer sua uma outra distinção central em James. À injunção de James a observar que a reprodução (i.e., a lembrança secundária) de um acontecimento "é um fato psíquico inteiramente diferente" se a comparamos com a percepção desse mesmo acontecimento como "coisa imediatamente passada", Husserl irá fazer eco ao escrever: "Que entre a lembrança que re-presenta novamente e a lembrança primária, que estende a consciência do agora, haja uma diferença fenomenológica enorme, é o que uma comparação atenta das duas espécies de vividos nos mostra" (HUSSERL, 1964, § 19, p. 63). Na Primeira parte das Lições de 1905, Husserl reprocha precisamente a Brentano $^{34}$ sua confusão da lembrança primária com a consciência de imagem. Brentano compreende a remanência do recém-passado no presente sob a forma de uma imagem produzida pela imaginação que uma "associação originária" 35 vincula ao novo presente, afetando-o com 
o momento temporal "passado". Mas desse modo torna-se impossível tanto perceber no sentido próprio uma mudança qualquer ${ }^{36}$ quanto distinguir o tipo de consciência que é próprio ao recém-passado daquele que é próprio à rememoração. Com a distinção, que ele introduz, entre a "memória primária" e a "memória secundária", James abre assim a via que será adotada pela crítica husserliana da psicologia brentaniana do tempo:"A intuição do passado ela mesma, escreve Husserl, não pode ser uma figuração por imagem. É uma consciência originária” (HUSSERL, 1964, § 12, p.47).

Em função dos diferentes pontos de semelhança levantados, a descrição jamesiana da consciência do tempo mereceria portanto, mais ainda que a explicação brentaniana, o direito de se gabar de um "núcleo fenomenológico" (ein phänomenologischer Kern) ${ }^{37}$.

2. Wittgenstein e o presente fluente

A meditação filosófica levada a cabo por Wittgenstein acerca do tempo se realiza no modo da confissão. Como o nota S. Cavell, a confissão wittgensteiniana "contém tudo aquilo que uma confissão séria deve conter: um pleno reconhecimento da tentação (...) assim como a vontade de corrigi-la e de abandoná-la" (CAVELL, 1986, p. 55). Assim, Wittgenstein começa por expor, em 1929-30, ao longo de seu período dito "fenomenológico", uma certa concepção do tempo que exerce então sobre ele um grande fascínio ${ }^{38}$.É certamente mais adequado falar aqui do "reconhecimento" de uma tentação do que da adoção de uma tese filosófica ${ }^{39}$, uma vez que, de um lado, Wittgenstein nunca evoca essa concepção sem manifestar algumas reticências a seu respeito, e, de outro, nunca lhe concede mais que uma sucinta apresentação. Desde 1930 e ao longo dos anos que se seguem, Wittgenstein aplica a essa apresentação o trabalho de reflexão e de ruminação críticas próprias à terapia gramatical. Por essa ocasião, reconhece explicitamente a tentação à qual fora submetido anteriormente 40 e procura desemaranhar as razões que engendram essa tentação ${ }^{41}$.

Qual é a concepção evocada? Wittgenstein a enuncia muito claramente desde o fim do ano de 1929. É a de um presente "em fluxo permanente" (in ständingen Fluss), uma de cujas particularidades é a de que "ele desaparece antes que se possa ter pensado em se apoderar dele" (WITTGENSTEIN, Ms. 107, p. 1-2) 42:"Parece que aquilo que eu quero dizer verdadeiramente [quando digo que "tudo se escoa"] é que o presente desaparece incessantemente e, por assim dizer, não pode ser 
apreendido" (Ms. 108, p. 26-27). Esse "presente fluente" (fliehende Gegenwart) é claramente designado por Wittgenstein como aquele que a fenomenologia tem por tarefa descrever. Com efeito, ao texto precedente, Wittgenstein acrescenta: "O tipo de consideração que leva, por assim dizer, em um vale (Talkessel) do qual nenhum caminho pode nos levar para fora é a consideração do presente como a única coisa real (als des einzig realen)". Ora, alguns dias antes, Wittgenstein havia observado:"CCom a linguagem fenomenológica, tudo se passa como se nos encontrássemos em um pântano enfeitiçado onde tudo que é apreensível desaparece (wo alles Erfassbare verschwindet) (...) Mas qual é então a importância dessa descrição do fenômeno presente? Preocupar-se com essa questão parece inteiramente pueril e nós/ eu/ caímos em um beco sem saída (Sackgasse). E no entanto trata-se de um beco sem saída da maior importância pois tudo é atraído para ele; como se devêssemos nele encontrar a solução última do problema filosófico" (Ms. 105, p. 116) ${ }^{43}$.A meditação wittgensteiniana do tempo origina-se portanto no projeto fenomenológico wittgensteiniano, a respeito do qual contentar-me-ei com duas observações.

(l) Em primeiro lugar, uma dualidade de sentido afeta o termo "fenomenologia" no Wittgenstein de 1929, sem que essa dualidade seja claramente pensada e justificada. A "fenomenologia" (a) visa primeiro esclarecer a gramática (Die Phänomenologie stellt nur die Möglichkeiten fest) $)^{44}$ das proposições que descrevem a experiência imediata primária. Mas (b) esse esclarecimento supõe uma descrição efetiva dos fenômenos. Com efeito, se a possibilidade da linguagem fenomenológica é posta $a$ priori por Wittgenstein em razão do caráter dotado de sentido de nossa linguagem (a linguagem deve remeter-se diretamente à realidade primária no nível das proposições elementares), resta que sua realização passa por um estudo a posteriori dos próprios fenômenos, destinada a regular a multiplicidade da linguagem fenomenológica por aquela dos fenômenos (como ele esclarece em "Algumas observações sobre a forma lógica"45) e, desse modo, a "mostrar" (no sentido do Tractatus) as relações internas próprias à linguagem fenomenológica, isto é, suas regras gramaticais. Enfim, Wittgenstein considerou, ao longo do ano de 1929, que a multiplicidade fenomenal poderia ser estabelecida em parte empiricamente, o que significa que é necessária a realização efetiva da "descrição do fenômeno presente" da qual falamos acima.

Ora, é precisamente quando ele procura efetuar essa descrição 46 que Wittgenstein encontra a questão do tempo sob a forma da concepção do "presente fluente". E essa concepção tanto determina a descrição feno- 
menológica, uma vez que lhe atribui como tarefa dar conta do fenômeno presente, quanto a torna impossível, uma vez que, como eu o lembrei, o presente do qual se trata "desaparece antes que possamos pensar em nos apoderar dele". Não é de se espantar, então, que Wittgenstein justifique sua decisão de abandonar a elaboração de uma linguagem fenomenológica invocando o absurdo temporal no qual esta desemboca:“A suposição de que uma linguagem fenomenológica fosse possível e de que apenas ela diria verdadeiramente aquilo que devemos/ queremos exprimir em filosofia, essa suposição, creio eu, é absurda. Devemos nos virar com nossa linguagem ordinária e nos contentar em compreendê-la corretamente. $\mathrm{O}$ que significa que não nos devemos deixar levar por ela a proferir contrasensos. Querodizercom isso: o que chamo de signo deve ser aquilo que se chama de signo na gramática, algo no filme, não na tela" (WITTGENSTEIN, Ms 107, p. 176; grifo meu $)^{47}$.

$\mathrm{O}$ apelo à analogia cinematográfica visa ${ }^{48}$ distinguir entre o tempo do mundo primário fenomenal, o qual tanto se reduz exclusivamente ao presente quanto conhece um "fluxo permanente" (é a imagem sobre a tela), e o tempo do sistema secundário fisicalista, cujo presente se opõe a um passado e a um futuro 49 (é a imagem sobre a película). Desse modo, Wittgenstein rejeita a idéia, própria à sua fenomenologia ${ }^{50}$, de uma linguagem estritamente simultânea àquilo que ela descreve, uma vez que isso exigiria uma linguagem cujas proposições se reduzissem a um ponto temporal sem extensão, correspondente ao "presente fluente", desprovido de espessura temporal na medida em que desaparece tão logo surgiu. Em outras palavras, o "absurdo" temporal da linguagem fenomenológica levaria direto ao fantasma filosófico de um "som inarticulado" 51 que evidentemente não pode constituir uma linguagem.

(2) Minha segunda observação relativa ao projeto fenomenológico wittgensteiniano já não diz mais respeito ao modo pelo qual esse projeto faz surgir a problemática do tempo na reflexão de Wittgenstein e lhe confere uma importância nova, mas visa precisar a concepção do tempo que o projeto fenomenológico pressupõe e que por isso mesmo o condena. Dentre os raros comentários consagrados ao tema do tempo em Wittgenstein, duas propostas se apresentam em resposta à questão da origem da concepção provisoriamente adotada e depois criticada por Wittgenstein.A primeira ${ }^{52}$ avança a idéia de uma origem heracliteana via leitura de Platão. A outra sugere a fonte russelliana ${ }^{53}$. Mas uma leitura atenta substitui essas duas hipóteses, que algumas objeções nos proíbem de subscrever ${ }^{54}$, pela fonte jamesiana dos Principles of Psychology55: é nessa 


\section{8}

obra que Wittgenstein vai buscar em larga medida a concepção do tempo que ele toma em consideração em 1929. Uma análise de detalhe mostrao facilmente.

Em particular, podemos nos lembrar, em primeiro lugar, que James remete explicitamente seu conceito de "stream of thought" (ou "stream of consciousness") à célebre afirmação heracliteana: "seja lá o que se puder dizer acerca da corrente da vida, escreve ele, da corrente da sensação elementar, seria certamente verdadeiro dizer, como Heráclito, que nunca descemos duas vezes no mesmo rio"56 - texto ao qual responde diretamente a seguinte caracterização do "specious present": "Seu conteúdo está submetido a um fluxo incessante"57. Podemos, em seguida, ressaltar o fato de que o "presente fluente" aparece claramente na abertura do Capítulo XV: “Onde está esse presente? Ele escorreu entre nossos dedos, voou antes que o pudéssemos tocar, fugiu no instante de seu surgimento"(JAMES, 1981, p. 573) ${ }^{58}$. Enfim, Wittgenstein, por meio da analogia cinematográfica, procura conferir uma figura metafórica ao "specious present" de James, uma vez que a imagem sobre a tela é dotada das mesmas características essenciais que o datum do presente psicológico: ela é tanto sempre presente (o pseudo-presente "mantém-se permanente") quanto sempre cambiante ("Seu conteúdo está submetido a um fluxo incessante”; Cf. JAMES, 1981, p. 593). Notarse-á igualmente que as duas tentações filosóficas do mobilismo (“Alles fliesst") e do solipsismo instantaneísta ("Nur die Erfahrung des gegenwärtigen Augenblicks hat Realität") correspondem às duas características do "specious present" e aparecem estreitamente ligadas uma à outra quando da sua primeira ocorrência, no manuscrito 108 (WITTGENSTEIN, Ms 108,p.1).

A presença da herança jamesiana relativa à concepção do tempo, portanto, afirma-se com força no Wittgenstein de 1919-30. Ela permite precisar que a reflexão wittgensteiniana sobre o tempo surge no contexto do debate filosófico relativo à consciência do tempo. No entanto, é claro desde já que Husserl e Wittgenstein não herdam os mesmos elementos da análise de James: a herança husserliana retém antes de tudo o alargamento temporal do campo da intuição, ao passo que a herança wittgensteiniana retém a figura do presente fluente. A oposição que desenvolverei adiante encontra aqui sua primeira expressão.

3. O parentesco de 1929

Qual é a conseqüência imediata dessa filiação comum? Ela reside em um 
certo parentesco entre as posições filosóficas respectivas de Husserl e do Wittgenstein de 1929, em particular no tocante aos três pontos seguintes.

(1) Ambos evocam a idéia de um fluxo absoluto primário situado aquém de todo objeto físico: é o fluxo da consciência, i.e., o do dado experiencial efetivo, com esta restrição de que não encontramos, em Wittgenstein, nenhum equivalente da distinção husserliana entre o fluxo constitutivo absoluto e o fluxo das aparições imanentes. Esse fluxo primário, em primeiro lugar, designa o fundamento sobre o qual se edifica o mundo dos objetos e dos acontecimentos físicos. Caracteriza-se, além disso, pela dupla propriedade de ser sempre presente e incessantemente cambiante: à descrição jamesiana do "specious present" como conjuntamente "permanente" e "submetido a um fluxo incessante", Husserl responde pela descrição do "campo de presença originário" como um fluxo permanente e Wittgenstein pelas duas propriedades essenciais do mundo que as duas afirmações mobilista e solipsista instantaneísta pretendem exprimir. Esse fluxo define, por fim, uma subjetividade absoluta: à "vida subjetiva (subjective life)" que James identifica com a "corrente de consciência" 59 Husserl responde com a concepção do "fluxo constitutivo do tempo como subjetividade absoluta" 60 e Wittgenstein com a idéia de que as afirmações mobilista e solipsista instantaneísta tentam dizer algo que "pertence à essência do mundo". Convém aqui lembrar que os textos contidos nos manuscritos de 1929-30 ainda estão fortemente impregnados pelas concepções provindas do Tractatus e, em particular, dessa idéia de que o sujeito metafísico e o mundo são uma só e mesma coisa ("Eu sou meu mundo"61).

(2) Além disso, o fluxo absoluto da experiência imediata é o fluxo do tempo, isto é, a temporalidade primordial da qual é derivado o tempo objetivo do mundo físico.Vimos que James faz do sentimento do tempo engendrado no "specious present" (isto é, do "sensible present" ou "intuited time") "o original e o modelo de todos os instantes concebidos (the original and prototype of all conceived times)" (JAMES, 1981, XV, p. 594). Por sua vez, Husserl pretende desvelar o modo pelo qual se opera a constituição do tempo coisal no fluxo constitutivo do tempo ${ }^{62}$. Wittgenstein evoca, ele próprio, uma relação de construção que leva do "specious present" ao tempo do segundo sistema. Nesse sentido, ele escreve: "Não seria assim: /?/ o fenômeno (specious present) contém o tempo, mas não está no tempo? Sua forma é o tempo, mas ele não tem nenhum lugar no tempo" (Ms 105, p. 114)63. Além disso, mesmo se o texto de James pode dar margem a dúvidas a esse respeito ${ }^{64}$, Husserl e o Wittgenstein de 1929-30 


\section{0}

parecem ter extraído dos Principles a idéia de que o fluxo da consciência $e ́$ o fluxo de uma temporalidade primária que serve de fundamento a toda outra forma de tempo.

(3) Por fim, o fluxo absoluto do tempo fenomenal escapa à linguagem, cuja inadequação exige que ela venha ser substituída por um outro modo de manifestação. James sublinha assim nos Principles até que ponto a linguagem, pelo fato de não ter sido construída para fins de investigação psicológica., representa tanto um obstáculo para a descrição fiel quanto uma fonte de erros. Em particular, ela fracassa em descrever as "partes transitivas (transitive parts)" da vida da consciência, isto é, o caráter fluente desta, e está na origem da "ilusão do psicólogo (psychologist'sfallacy)" que tem como efeito passar ao largo da propriedade do presente psicológico de ser temporalmente estendido65. Husserl manifestará a mesma frustração com respeito às possibilidades que nossa linguagem, regrada pelo constituído, põe à disposição da descrição fenomenológica. Acerca da descrição do fluxo constitutivo, ele escreve:"Para tudo isso, os nomes nos faltam" (HUSSERL, 1964, § 36), antes de remeter seu interlocutor à intuição fenomenológica: "Mas o que é que isso quer dizer? Aqui não se pode dizer nada além de 'veja" (HUSSERL, 1964, § 38). De modo muito claro, Wittgenstein reconhece ele próprio a incapacidade da linguagem em exprimir a temporalidade primária do mundo fenomenal, com esta única diferença de que se trata para ele de uma incapacidade lógica e não de uma inadequação de direito contornável e de que essa indizibilidade lança suspeitas (como o veremos) sobre a própria imagem do presente fluente: "O que pertence à essência do mundo, escreve, a linguagem não pode dizê-lo/ exprimi-lo. Por isso não pode dizer que tudo se escoa. A linguagem pode dizer apenas aquilo que podemos nos representar de outro modo" (WITTGENSTEIN, Ms 108, p. 1) ${ }^{66}$.

\section{II - Husserl e Wittgenstein, críticos da psicologia empírica da consciência do tempo}

O parentesco filosófico entre o segundo Wittgenstein e Husserl quanto à questão do tempo estende-se para além das poucas conexões que acabo de indicar. Wittgenstein e Husserl compartilham, com efeito, uma posição crítica para com a psicologia empírica, que Husserl encontra em Brentano e Wittgenstein em James e Russell67. De modo mais preciso, a tese visada é aquela que sustenta que apenas o presente seria real ${ }^{68}$ e que, em conse- 
qüência, a relação com o passado deveria ser compreendida e construída com a ajuda de um material psíquico exclusivamente presente - o que não vai sem pôr dificuldades para o tratamento reservado pela psicologia empírica ao fenômeno da lembrança. Husserl e Wittgenstein criticam ambos a idéia que se encontra no fundamento dessa análise, isto é, a de uma exclusividade ontológica do presente. Mas podemos nos perguntar se, ao fazê-lo, eles prolongam essa abertura descritiva que é o alargamento temporal da intuição realizado por James, ou se suas relações respectivas com o pensamento jamesiano a isso se opõem, como parece indicá-lo já a diferença naquilo que cada um deles retém desse pensamento ${ }^{69}$.

1A A crítica compartilhada por Husserl e Wittgenstein

(1) A relação presente-passado. Uma das afirmações filosóficas tomadas como alvo por Wittgenstein no início dos anos $1930^{70}$ é a célebre hipótese cética de Russell:"Não se pode fazer valer nenhuma impossibilidade lógica contra a hipótese segundo a qual o mundo veio à existência há cinco minutos, exatamente tal como era então, com habitantes que 'se lembravam' de um passado totalmente irreal" (RUSSELL, 1997, IX, p. 159) ${ }^{71}$. Essa afirmação defende a tese de inspiração humeana segundo a qual é logicamente possível que eu me lembre de algo sem que nada no passado corresponda efetivamente àquilo de que minha lembrança é lembrança. Em termos mais explícitos, isto significa, primeiro, que posso me lembrar de ter percebido $\mathrm{N}$ na rua ontem, ao passo que $\mathrm{N}$ não estava na França naquele momento ${ }^{72}$, mas, mais ainda, que eu posso me lembrar de ter percebido $\mathrm{N}$ na rua ontem, ainda que não o tenha percebido, e mais globalmente, ainda mesmo que ontem nunca tenha existido $^{73}$ : o passado, isto é, notadamente, minhas experiências passadas, podem muito bem ser "totalmente irreais", não terem nunca ocorrido, ainda mesmo que me lembre delas."Não é logicamente necessário à existência de uma crença mnêmica, escreve Russell, que o acontecimento rememorado se tenha produzido, nem tampouco que o passado tenha existido de alguma maneira" (RUSSELL, 1997, p. 159). Com esse tipo de afirmação, Russell defende aquilo que constitui segundo Husserl o próprio da psicologia empírica do tempo, que pergunta (ainda segundo Husserl): "por que uma consciência inicial, começando por uma lembrança recente, sem ter havido percepção prévia, não deveria ser concebível?" (HUSSERL, 1964, § 13, p.48).

A questão levantada por essa discussão diz respeito à natureza da relação do presente de consciência com a experiência passada e, mais 


\section{2}

geralmente, do presente com o passado. Aos olhos de Russell e de Brentano $^{74}$ (e da psicologia empírica em geral), a relação em questão é "externa", i.e., contingente. Como sustenta Russell, é perfeitamente concebível que apenas o presente exista e que o passado não seja mais que uma aparência; nenhuma necessidade lógica vincula um ao outro. $\mathrm{Na}$ extremidade oposta, Husserl e Wittgenstein defendem a idéia de que a relação considerada é "interna”, i.e., necessária. Assim, contra a idéia de um nexo simplesmente factual ("de facto") entre lembrança primária e percepção, Husserl afirma: "Pelo contrário, professamos que é necessário a priori que a retenção seja precedida de uma percepção e, portanto, de uma impressão originária correspondente" (1964, § 13, p. 48). No mesmo sentido, Wittgenstein sustentou, como o relata G.E.Moore, que "o termo 'agora', no sentido em que o empregamos habitualmente e no qual Russell sem dúvida alguma o empregava, possui um sentido tal que uma parte daquilo que exprimimos quando dizemos acerca de um acontecimento que ele ocorre 'agora' consiste em fazer valer que ele era precedido por outros acontecimentos dos quais nos lembramos" (MOO RE, 1997, p. 138) ${ }^{75}$. Contra a hipótese inverificável de Russell, Wittgenstein faz portanto valer uma necessidade gramatical: a afirmação de Russell só será suscetível de ganhar algum sentido se considerarmos que a dúvida com relação à lembrança possa ser generalizada - o que é infirmado pelo uso ordinário de nossa linguagem, segundo Wittgenstein ${ }^{76}$.

Wittgenstein e Husserl são portanto levados a fazer valer que o passado está necessariamente ligado ao presente - atribuindo, decerto, dois estatutos diferentes a essa necessidade - e que, em conseqüência, a ontologia do tempo adotada pela psicologia empírica ${ }^{77}$ não é sustentável: Husserl rejeita assim a afirmação "só é real a determinação do presente"78 e Wittgenstein, as afirmações "só a experiência do momento presente é real"79 e "só o presente é real" (WITTGENSTEIN, 1999 p. 182).

(2) A lembrança. A conseqüência maior das observações precedentes reside na crítica, desenvolvida por Husserl e Wittgenstein, da análise psicológica da lembrança - quer ela seja primária, quer secundária. $\mathrm{O}$ psicólogo defronta-se, de fato, com uma dificuldade de monta quando aplica sua ontologia ao fenômeno da lembrança: se, como ele sustenta, só o presente é real, a relação do presente com o passado que caracteriza o fenômeno da lembrança deve caber inteira no presente, uma vez que só dispomos dele. Mas como construir uma relação com o passado por meio apenas do presente? Em particular, se consideramos que a lembrança consiste na cópia do acontecimento do qual nos lembramos, o que é que, 
no vivido psíquico presente da lembrança, permite saber que nos defrontamos realmente com uma lembrança, e não, por exemplo, com uma simples ficção?

Diante dessas questões, a linha argumentativa adotada por Husserl e Wittgenstein visa contestar a redução da lembrança a um conteúdo psíquico exclusivamente presente. Essa redução é operada tanto por Russell $^{80}$ quanto por Brentano ${ }^{81}$. Segundo eles, o ato psíquico da lembrança, e, em particular, o momento temporal passado (em Brentano) $)^{82}$ e o "sentimento da passeidade" (em Russell) ${ }^{83}$, pertencem exclusivamente ao presente. Evidentemente, isso não significa de modo algum que Brentano e Russell dêem a mesma explicação da lembrança primária. Ao passo que a psicologia brentaniana assegura a permanência do recém-passado no presente sob a forma de uma imagem criada e associada imediatamente ao presente pela imaginação, a psicologia russelliana compreende a lembrança primária como uma atenuação, um enfraquecimento ("a fading process") da sensação recém-passada. Segundo Russell, é portanto a mesma sensação que se prolonga e diminui de intensidade, ao passo que, segundo Brentano, uma imagem se substitui à sensação e a representa. Nem por isso deixam essas duas explicações de desembocar no mesmo resultado: inflectem o passado imediato no presente e encerram irremediavelmente a consciência no exclusivo presente.

Essa redução ao presente leva a análise psicológica a adotar uma concepção pictorial da lembrança, isto é, a considerar que a lembrança é formada por uma imagem mental presente 84 , cópia do acontecimento passado à qual se associa um momento ou um sentimento que deveria indicar o valor temporal do acontecimento representado.A conseqüência principal dessa concepção é a de considerar que a lembrança, assim como a imagem, pode de jure ser comparada àquilo de que ela é a lembrança. Com efeito, assim que submetemos a lembrança à lógica da imagem, regramos sua verdade pela fidelidade com a qual ela copia o acontecimento doravante passado. Depois, constatando a impossibilidade de operar com essa comparação, o passado será declarado inacessível ou irreal e a lembrança essencialmente incerta. Não é de se espantar, então, que Russell observe, em apoio a sua explicação cética da lembrança: "o que precisaríamos fazer para encontrar um meio de comparar a imagem presente e a sensação passada?(...) é a própria possibilidade da comparação que é dificil de compreender" (RUSSELL, 1997, p. 158-159; grifo meu) ${ }^{85}$.

Contra a psicologia empírica, Husserl e Wittgenstein rejeitam, em primeiro lugar, a redução ao presente. Husserl observa assim: "Aquilo de 


\section{4}

que nos lembramos, a bem dizer, não é agora - senão não seria passado, mas presente (...)" (HUSSERL, 1964, § 13, p. 50) - e, desse modo, ele se opõe, sem o saber, à afirmação russelliana:"as ocorrências que chamamos conhecimento do passado são logicamente independentes do passado; elas são inteiramente analisáveis em conteúdos presentes" (RUSSELL, 1997, p. 160)86. Para Husserl, o rememorado não é portanto um conteúdo "real" (reell) da consciência 87 que seria "interpretado" ("concebido") como algo passado; a lembrança não é a percepção de algo efetivamente presente ao qual se atribuiria a qualidade "passado"88. Nada é sensivelmente percebido na consciência da lembrança (primária ou secundária) ${ }^{89}$. Wittgenstein observa também: "Quando digo 'Ele estava aqui meia hora atrás' - isto é, quando eu o digo de memória - não se trata da descrição de um vivido presente" (1984b, II, xiii, p. 579) ${ }^{90}$, e ele defende a mesma idéia de que a relação com o passado não é derivada, "deduzida"91 a partir de um vivido psíquico presente.

Independentemente do modo pelo qual a justificam, a exigência se impõe portanto a Husserl e a Wittgenstein de reconhecer a originariedade do caráter "passado" do acontecimento rememorado, sem reduzi-lo a um conteúdo psíquico presente. É a exigência descritiva da fenomenologia que conduz Husserl a trazer à luz um modo de consciência de pleno direito, "originário", no caso da lembrança, e não fundado em uma consciência do presente: a intencionalidade específica da lembrança primária é um modo necessário do aparecer, e não a marca de uma fraqueza da consciência que a condenaria a dever satisfazer-se com pálidos substitutos da experiência intuitiva presente ${ }^{92}$. Quanto a Wittgenstein, é a exigência descritiva da gramática que o conduz a fazer valer que o conceito de lembrança nem sempre autoriza a intervenção de uma dúvida e que, de modo mais geral, o presente se distingue essencialmente do passado e, por conseguinte, o implica necessariamente. Assim como Husserl, portanto, ele recusa a pertinência de uma concepção da lembrança como "uma forma secundária da experiência, em comparação com a experiência do presente" (WITTGENSTEIN, 1984a, § 52 c, p. 84) ${ }^{93}$. Cada um deles, portanto, substitui os impasses da explicação psicológica por uma certa prática da descrição reveladora da originariedade do passado.

Mas se a relação com o passado própria à lembrança é uma dimensão originária (intencional ou gramatical), a lembrança não pode consistir numa imagem ${ }^{94}$ e a relação da lembrança com o lembrado não pode participar da lógica da imagem. Por isso, Husserl e Wittgenstein rejeitam 
ambos, em segundo lugar, a pertinência da questão russelliana versando sobre a possibilidade da comparação: essa questão não pode ter sentido, pois ela se engana sobre a própria natureza da lembrança ${ }^{95}$. A retenção husserliana e aquilo que Wittgenstein chama "a memória como fonte do tempo"96 fornecem uma manifestação do próprio passado e não uma simples imagem semelhante cuja fidelidade seria sempre suspeita. Caberia então considerar que, como herdeiros fiéis da abertura descritiva realizada por James nos Principles, Husserl e Wittgenstein refutariam assim descritivamente a exclusividade ontológica conferida pela psicologia empírica ao presente?

\section{Duas avaliações filosóficas diferentes da exclusividade do presente}

$\mathrm{Na}$ verdade, se de fato encontramos uma crítica da psicologia empírica acerca da questão do tempo tanto em Husserl quanto em Wittgenstein, e se o alvo principal dessa crítica consiste de fato na exclusividade do presente, cabe no entanto acrescentar que essa crítica não tem o mesmo sentido nos dois pensadores e que essa divergência provém justamente de duas apropriações quase opostas das análises jamesianas. É à explicação dessa divergência que irei agora dedicar-me. Essa explicação deve trazer à tona aquilo que separa o tratamento filosófico ao qual Wittgenstein submete a questão do tempo daquele proposto por Husserl.

(1) Que sentido específico tem, em Husserl, a crítica da exclusividade conferida pela psicologia ao presente? Para responder essa pergunta, é primordial observar que Husserl não contesta a pertinência da questão posta pela psicologia empírica, qual seja:"como compreender a presença do passado no presente?" O que ele contesta é a resposta fundada na idéia de que a relação com o passado própria à lembrança deva ser estabelecida apenas por meio de um material psíquico presente, pois essa resposta lhe parece tornar a questão um problema insolúvel. A estratégia adotada por Husserl consiste, desde então, em transportar a questão da psicologia empírica, para resolvê-la, do nível ontológico para o nível fenomenológico, a fim de que uma correta descrição revele o nexo necessário que une percepção e retenção, isto é, a passagem contínua da percepção na não-percepção ${ }^{97}$ que caracteriza o duplo movimento de escoamento incessante e de manutenção permanente da vida da consciência. Assim, prolongando o tema jamesiano (dirigido contra o atomismo sensualista) da continuidade do "stream of thought", Husserl mostra que a unidade do presente e do passado é primeira e que o ponto de partida da psicologia empírica - a separação - é abstrato. A seus olhos, a afirmação "apenas 


\section{6}

a determinação do presente é real" peca portanto pelo esquecimento de uma distinção essencial, i.e., a da imanência efetiva (reell) e da imanência intencional: o psicólogo faz como se apenas o efetivo fosse dado.Em outras palavras, segundo Husserl, o psicólogo acredita estar encerrado no presente porque omite uma dimensão originária da vida da consciência, a do passado, dado na retenção, que ele assimila ao presente. Para Husserl, é o erro cometido acerca do passado que conduz ao impasse.

(2) A crítica wittgensteiniana, de seu lado, sustenta que é um erro cometido acerca do presente que está na origem da exclusividade conferida pela psicologia a essa determinação temporal e, portanto, na origem dos problemas que dela resultam. Se o psicólogo e, na sua esteira, inúmeros filósofos pensam que estamos sempre no presente, isto se dá, segundo Wittgenstein, antes de tudo porque se equivocam sobreo presente. Uma certa concepção do presente os conduz a não poder compreender o passado a não ser como algo presente. Antes que em uma concepção, Wittgenstein fala aliás de uma mitologia que se manifesta sob a forma de uma certa "tendência" ou "tentação" - e, no caso, trata-se daquela que consiste, diz Wittgenstein, em "pôr o presente sobre um pedestal" ou em "coroá-lo"98. Ali onde Husserl acredita localizar um esquecimento descritivo (o da intuição originária do passado imediato) que conduz a uma confusão (a do passado com o presente),Wittgenstein acredita identificar a insistência de um mito filosófico, de uma imagem que nos mantém cativos, qual seja, aquela que se exprime em afirmações como: "Agora é sempre agora" ou "Estamos sempre no presente".

$\mathrm{Na}$ verdade, a divergência que acabo de apresentar expressa o fato de que Wittgenstein adota, com relação à questão endereçada pelo psicólogo ao fenômeno da lembrança, uma atitude completamente diferente daquela adotada por Husserl. Com efeito, ele pergunta menos: "como pode haver uma relação com o passado se estamos limitados ao presente?" do que : "qual é a concepção do tempo e, especificamente, do presente que leva a ver como problemática a possibilidade de 'sair do presente' e a elaborar uma explicação da lembrança apoiada unicamente em um material psíquico presente?" Wittgenstein, portanto, não cogita de modo algum trazer uma solução para o problema do modo de remanência do passado no presente, como o faz Husserl ao voltar ao nível puramente descritivo da fenomenologia, mas ele se interroga sobre a concepção implícita do tempo que confere sua tensão problemática a esse tema de investigação.A questão da psicologia é, portanto, tratada como sintoma de certos erros cometidos para com a 
linguagem ordinária e não como o enunciado pertinente de um problema dotado de sentido.

De um ponto de vista interno ao pensamento wittgensteiniano, vemos que as observações precedentes chamam por um comentário renovado das observações que o filósofo austríaco consagrou à memória ao longo de seu "segundo período". Os comentadores 99 , com efeito, tratam esse conjunto de observações como se ele fosse autônomo. Geralmente expõem as diferentes críticas endereçadas por Wittgenstein às concepções psico-filosóficas clássicas da lembrança, na linha de frente das quais se encontram as da lembrança como vestígio, da lembrança como vivido e da lembrança como imagem. Mas esquece-se de notar então que as diferentes concepções visadas têm como ponto comum defender a idéia de que a lembrança é constituída por um material psíquico exclusivamente presente e que Wittgenstein pensou longamente, de modo mais global, a tentação filosófica de reservar a realidade apenas à experiência presente. A correta compreensão das observações relativas à memória não pode portanto passar-se de sua reintegração no seio do pensamento wittgensteiniano do tempo e, em particular, do estudo que ele consagrou ao mito do presente.Aos olhos de Wittgenstein, a teoria da lembrança-cópia (alvo privilegiado da crítica wittgensteiniana) é suscitada pela idéia de que apenas a experiência presente é real. E é precisamente contra ela que, no início dos anos 1930, Wittgenstein volta por repetidas vezes à distinção entre, de um lado, a memória considerada como a "fonte do tempo", isto é, a memória como único critério de determinação do passado e, de outro lado, a memória considerada como um testemunho entre outros dos acontecimentos passados: fazer valer o caso em que a memória é o passado é, para Wittgenstein, fazer valer uma "originariedade" gramatical do passado que proíbe reduzir a lembrança a uma imagem presente ${ }^{100}$.A crítica wittgensteiniana do conceito psicológico e filosófico da memória, tal como se elabora na segunda metade dos anos 1940 não pode ser separada, sem prejuízos, de um pensamento do tempo, como tampouco do tratamento conferido ao conceito de memória no início dos anos 1930101 .

(3) Vemos, portanto, que os diferentes pontos de interseção entre Husserl e Wittgenstein em seu tratamento do tempo que foram levantados encobrem profundas divergências, a começar por aquela que se afirma entre suas respectivas críticas da exclusividade do presente. Ora, parece-me que essas divergências encontram sua razão de ser em um desacordo ainda mais profundo, que diz respeito ao juízo emitido por 


\section{8}

Husserl e Wittgenstein acerca da análise jamesiana e, mais particularmente, acerca de seu "núcleo fenomenológico". Na verdade, a crítica que Wittgenstein elabora projeta-o para fora dos quadros da análise de James, pois ele suspeita que o próprio "núcleo fenomenológico" jamesiano (isto é, a concepção de um presente incessantemente fluente) seja errôneo, ao passo que a crítica que Husserl desenvolve o mantém nesses quadros ao preço de certas correções - por certo importantes - trazidas à descrição jamesiana, que, em conseqüência, vê-se conservada em alguns pontos essenciais. A idéia de um presente de consciência que se escoa incessantemente é um desses pontos.

\section{III - Husserl e Wittgenstein: duas críticas opostas do "núcleo fenomenológico" jamesiano}

Para justificar a afirmação segundo a qual Husserl e Wittgenstein mantêm relações opostas com o "núcleo fenomenológico" jamesiano, cabe comparar suas respectivas apropriações das análises de James relativas ao tempo e, mais precisamente, os argumentos críticos que cada um deles endereça ao psicólogo americano.

1. Husserl e a purificação do núcleo fenomenológico jamesiano.

A admiração que Husserl tem pelo trabalho de James e o papel de precursor da fenomenologia que ele se apraz freqüentemente em lhe atribuir não devem dissimular o fato de que a descrição husserliana, em particular em sua investigação da consciência do tempo, traz algumas correções maiores à descrição jamesiana. Antes de tudo, o fato de que James trabalha e pensa como psicólogo constitui certamente um limite de monta, do ponto de vista da fenomenologia, em particular pelas seguintes razões. Convém primeiro observar que em James, como na psicologia em geral, o que está em causa "é o material de sensação original, do qual nasce, no indivíduo humano e mesmo na espécie, a intuição objetiva do espaço e do tempo" (HUSSERL, 1964, § 2, p. 15). Em outras palavras, James aborda como fatos psicológicos contingentes aquilo que a redução fenomenológica revela como modos necessários do aparecer: para ele, o fato de que a percepção de uma melodia supõe uma certa ressonância do recém-passado no presente prende-se largamente à conformação psicofísica do ser humano. Para Husserl, em compensação, o aparecer da melodia caracteriza-se de modo a priori e necessário, independentemente 
de todo sujeito psicofísico natural ${ }^{102}$. A natureza factual dos objetos de descrição apreendidos por James diminui portanto fortemente o alcance fenomenológico dessa descrição.

Assim, no capítulo XV dos Principles, James retoma com a mão da explicação aquilo que ele havia dado com a mão da descrição. Em outros termos, a abertura descritiva evocada relativamente ao alargamento temporal da intuição volta em larga medida a fechar-se em função da preocupação com uma explicação causal da percepção do tempo, fundada na determinação dos fenômenos mentais pelos acontecimentos fisiológicos. Se a dupla tarefa que James confere à psicologia ${ }^{103}$, de descrever e de explicar a vida mental, não é sempre respeitada no seio dosPrinciples, o tratamento do tempo, de seu lado, não lhe faz agravo ${ }^{104}$ : o capítulo XV tece, de fato, os dois fios da descrição do sentimento do fluxo do tempo e da sua explicação fisiológica. James repete assim que uma certa "causa" deve poder explicar a remanência do recém-passado no presente ${ }^{105}$. E ele a indica precisamente nos termos seguintes: "há, a cada instante, uma certa acumulação de processos cerebrais que se sobrepõem uns aos outros (overlapping each other), os mais fracos dos quais constituem a fase morrente dos processos que, pouco antes, conheciam um grau de atividade máxima" (JAMES, 1981, p. 597-598). A conseqüência lastimável dessa explicação é que a intuição do passado imediato se torna a contraparte mental de um processo fisiológico que é simultâneo ao processo fisiológico da experiência estritamente presente. Do ponto de vista fisiológico, a intuição do recém-passado consiste na percepção de uma ressonância nervosa efetivamente presente, e é em razão de sua pouca vivacidade que essa ressonância é vivida mentalmente como o eco de um estímulo desaparecido. Por conseguinte, a psicologia jamesiana do tempo, quando se acresce de sua vertente explicativa apoiada na vida fisiológica, cai sob os golpes da crítica husserliana 106 à qual ela havia de início escapado em razão de sua correção descritiva: a intuição do passado imediato repousaria sobre um momento sensível efetivamente (reell) presente107. Ela reencontra assim a posição da psicologia empírica.

Aos olhos da fenomenologia, a manobra explicativa própria à psicologia desencaminha James em outro ponto importante. A gênese psicológica da "percepção do tempo" proposta no capítulo XV dos Principles considera, com efeito, que o "stream of thought" deve ser percebido como um fluxo para que a percepção de um objeto persistente ou de um processo temporal objetivo seja possível. Dito de outro modo, uma certa remanência do recém-passado da percepção no presente da percepção é 
necessária para que aquilo que é percebido o seja segundo sua temporalidade. Sem essa percepção da sucessão das percepções, nada de percepção da sucessão objetiva. Mas se, desse modo, o fluxo de consciência ocupa a função de condição psicológica de aparição de um objeto ou de um processo temporais, resta que esse fluxo é ele próprio um processo temporal percebido. Por conseguinte, requer, a esse título, as mesma condições de percepção que aquelas que ele assegura aos objetos persistentes e aos processos temporais objetivos. Somos, portanto, confrontados seja com a dificuldade de um círculo vicioso (o fluxo suporia sua própria percepção para poder ser percebido), seja com a de uma regressão ao infinito (seria preciso pôr um fluxo mais primitivo que permitiria a percepção do "stream of consciousness", mas que exigiria por sua vez um fluxo permitindo sua própria percepção, etc. $a d$. inf.).

Husserl tinha plena consciência dessa dificuldade. Para ele, o erro de James prende-se ao fato de não ter conseguido ver a relação deconstituição que vincula o fluxo da consciência absoluta constitutiva e o fluxo do tempo constituído (seja ele imanente ou transcendente). Embora seja sensível ao problema posto pela objetivação do fluxo de consciência ${ }^{108}$, isto é, ao seu caráter não constitutível assim que se quer apreendê-lo em sua vida mesma, James evoca no entanto uma simples relação de justaposição estática 109 entre a temporalidade intuitiva do "specious present", de um lado, e o passado e o futuro "concebidos", de outro lado, que ele considera enquadrarem o tempo intuitivo. Por conseguinte, a dificuldade de objetivar o fluxo ${ }^{110}$, em James, prende-se antes à estrutura do presente fluente do que a uma reflexão sobre a distinção entre o constitutivo e o constituído. Husserl, pelo contrário, pelo fato de que o fluxo absoluto enquanto constitutivo não é algo constituído, recusa ver no "campo temporal originário" um pedaço do tempo objetivo111. Ora, a constituição do tempo encontra um de seus principais fenômenos na intencionalidade da retenção. Se se pode duvidar da tematização, no seio do pensamento de James, da intencionalidade da consciência, a intencionalidade retencional específica claramente escapa à análise psicológica do tempo. A redução da intuição do recém-passado à face mental de uma ressonância fisiológica está aí para confirmá-lo. De um ponto de vista husserliano, não é de se espantar, então, que a análise de James não possa escapar à dificuldade evocada, uma vez que é a retenção que lhe teria permitido esquivá-la ${ }^{112}$. Aos olhos de Husserl, apenas o tema da auto-constituição do fluxo absoluto por meio da dupla intencionalidade ("transversal" e "longitudinal") da retenção permite sair tanto do círculo vicioso quanto da regressão. 
No entanto, essa correções maiores não arranham em nada o "núcleo fenomenológico" que elas extraem de sua ganga psicológica. Se a problemática da constituição não entra em jogo na análise jamesiana da consciência do tempo, resta que o presente estendido do "specious present", considerado como presente de consciência a uma só vez "permanente" e "submetido a um fluxo incessante", fornece a Husserl o quadro descritivo no seio do qual ele instala o tema da retenção e de sua atividade constitutiva. Portanto, a idéia de uma intuição do passado distinta da lembrança secundária deve a esse título ser tida como o primeiro passo, decisivo, em direção a uma fenomenologia da consciência do tempo. Era preciso que James o tivesse dado para que Husserl desse o segundo.

2. Wittgenstein e a dissolução do núcleo fenomenológico jamesiano.

Wittgenstein, de seu lado, efetua uma ampla guinada que, na verdade, o faz sair do quadro descritivo estabelecido por James. Assim, se ele não se atarda sobre a problemática tratada por James, e retomada por Husserl, do modo de presença do recém-passado no presente de consciência, é porque ele nutre as maiores suspeitas para com a representação que justifica essa problemática, qual seja, a do fluxo de consciência ("das Strömen des Bewusstseins"113, “der ständige Fluss der Erscheinung"114) e de um presente que incessantemente nos escaparia ("die fliehende Gegenwart"115). Wittgenstein entra portanto no debate psicológico e filosófico da consciência do tempo contestando o pressuposto comum a muitos de seus participantes: o do modelo heracliteano de uma consciência incessantemente fluente, cuja fluência, de um modo ou de outro, definiria a temporalidade primordial. Pode-se localizar no seio do corpus wittgensteiniano várias análises destinadas a nos libertar dessa imagem que mantém cativos tanto James quanto Husserl, mas também o próprio Wittgenstein (pelo menos em 1929). Uma delas ${ }^{116}$ consiste em desemboscar uma confusão que, segundo Wittgenstein, está na origem ${ }^{117}$ da idéia da exclusividade do presente e da idéia do presente fluente da consciência, isto é, está na origem justamente da concepção heracliteana adotada por James e Husserl ${ }^{118}$. De encontro a essa concepção, Wittgenstein avança, em particular, as duas observações seguintes.

Em primeiro lugar, se a experiência imediata se define como a experiência presente, que sentido pode haver em falar de uma experiência imediata passada? A idéia de uma experiência imediata que seria primeiro presente antes de se afundar no passado é o produto da "transferência do conceito do tempo físico ao curso dos vividos imediatos" (WITTGENS- 


\section{2}

TEIN, 1984a, § 49, p. 81) ${ }^{119}$. Com efeito, considerar que uma experiência desapareceu no passado e que só conservamos dela uma cópia presente equivale a supor que essa experiência é algo diferente daquilo que aparece imediatamente, isto é, precisamente uma coisa suscetível de ser sem aparecer. Ora, na linguagem da experiência imediata (na "sintaxe" desse "modo de expressão", diz Wittgenstein) $)^{120}$, o passado é aquilo que aparece para a memória, e nada além. Assim como não se deve confundir o curso dos vividos imediatos com o tempo físico, tampouco se deve, portanto, confundir a memória como a "fonte do tempo" (die Quelle der Zeit) com a memória como "a imagem que conserva [mais ou menos bem] o acontecimento passado" (das aufbewahrte Bild des vergangenen Ereignisses): a primeira, própria à sintaxe da experiência imediata, é o passado e, por conseguinte, o único critério daquilo que é o passado (a distinção ser/aparecer não tem sentido no seu caso), a segunda constitui apenas um testemunho dentre outros possíveis acerca de um acontecimento com relação ao qual faz sentido dizer que ele é algo diferente daquilo que ele nos parece ser. A linguagem da experiência imediata não autoriza, portanto, a que se considere a lembrança como "um tipo de experiência secundária, em comparação com a experiência presente" 121 , o que significa que, de seu ponto de vista, não se pode dizer: "Posso apenas lembrar-me"122. Somente a linguagem própria aos acontecimentos físicos o permite ${ }^{123}$. Cabe sublinhar que o "presente" da experiência imediata, isto é, o da aparição, não é margeado por um passado no qual se afundariam os vividos de início presentes (nem por um futuro do qual teriam surgido), uma vez que aquilo que aparece como passado está incluído no campo fenomenal da experiência imediata. Não se pode portanto dizer que a experiência imediata é "presente", pois esse predicado temporal só tem sentido se puder ser distinguido de um passado e de um futuro ${ }^{124}$, ao passo que, do ponto de vista fenomenológico, a experiência imediata (assim como a imagem sobre a tela), por definição, não é margeada nem pelo passado nem pelo futuro, à diferença do "presente" das coisas e acontecimentos físicos (que correspondem às imagens sobre a película ${ }^{125}$. A confusão da gramática dos objetos e acontecimentos físicos com a da experiência imediata representa portanto, aos olhos de Wittgenstein, um perigo filosófico considerável ${ }^{126}$. Ora, tanto James quanto Husserl sucumbem a essa confusão ao considerarmos que os próprios vividos (a "Empfindung" husserliana 127 e o "feeling" jamesiano) formam um fluxo que comporta uma fase presente. 
Em segundo lugar, se Wittgenstein evidentemente não nega que a experiência imediata sofra uma mudança, ele contesta não obstante que essa mudança consista num fluxo que atravessaria o presente de forma incessante. Se recorrermos à analogia cinematográfica, como freqüentemente ele faz para esclarecer essa questão, diremos que a confusão indicada consiste em confundir, de um lado, a imagem sobre a tela e as mudanças da cena que ela apresenta e, de outro, as imagens da película cinematográfica que se desenrola: " Representamo-nos o vivido (das Erleben) como uma película cinematográfica, de tal modo que possamos dizer: essa imagem, e nenhuma outra, está nesse momento frente à lente [do projetor]" (WITTGENSTEIN, BT, § 102, p. 495) ${ }^{128}$. Uma das conseqüências dessa confusão é que mesmo aquilo que aparece sobre a tela como um objeto imóvel e idêntico a si mesmo parece sofrer um fluxo incessante: para que algo apareça como não sendo submetido a nenhuma mudança, é preciso que se sucedam na frente do projetor imagens idênticas; desse modo, confundir a imagem sobre a tela com a imagem sobre a película dá a impressão de que a primeira se escoa como a segunda, mesmo se a cena que ela apresenta não sofre aparentemente nenhuma mudança. Enfim, "tudo se escoaria ainda mesmo que tudo, na ordem da experiência, permanecesse como está" (WITTGENSTEIN, 1997, p. 161). E assim é engendrado o sentimento de que o fenômeno se subtrai incessantemente de nosso alcance: do ponto de vista da película, podemos ver uma imagem do filme antes, durante e após sua passagem na frente do projetor, ao passo que, do ponto de vista da imagem sobre a tela, só se pode vê-la durante sua breve passagem frente ao projetor. A tentação é quase irresistível de afirmar:"Tudo se escoa".

A confusão indicada traz na sua esteira conseqüências filosóficas consideráveis e, em primeiro lugar, a do solipsismo instantaneísta, que consiste em tomar por uma proposição dotada de sentido uma afirmação que procura descrever a essência do mundo: dizemos de início que a experiência imediata é presente, depois, em razão do caráter particular desse presente (cf. supra), acabamos por sustentar que ela é sempre presente, que não podemos sair desse presente e que apenas ele nos é dado. Enfim, encontramos a tentação de dizer que:"Apenas minha experiência presente é real"'129. Mas essa confusão produz igualmente uma certa ontologia do tempo, movimentada pela análise jamesiana da percepção do tempo ${ }^{130}$, que sustenta que "Apenas o presente é real"'131,e segundo a qual o presente é uma ilhota de realidade cercada pelo nada do passado e do futuro. Mas, segundo Wittgenstein: "Equivocamo-nos ao 
acreditar que o presente é incessantemente roído pelo passado" (WITTGENSTEIN, 1999, p. 182) ${ }^{132}$. Delineando a genealogia lingüística das concepções filosóficas esboçadas, Wittgenstein mostra, com efeito, seu caráter desprovido de sentido, uma vez que essas concepções repousam decididamente sobre uma incompreensão do funcionamento de nossa linguagem. Desde então, a James e a Husserl, que (cada um por razões diferentes) deploram o fato de que o fluxo absoluto da consciência escape ao alcance da linguagem, Wittgenstein retorque que não há nada, na verdade, que nossa linguagem fracassaria aqui em exprimir, isto é, que a incapacidade da linguagem da qual se queixam James e Husserl é apenas uma ilusão de incapacidade, uma vez que o fluxo absoluto é apenas uma ilusão de fluxo.

\section{Conclusão: Wittgenstein, crítico de Husserl? A questão do estatuto da analogia do fluxo}

Pode-se agora perceber toda a distância que separa as posições de nossos dois autores. Ali onde Husserl descobre um esquecimento descritivo da psicologia empírica e uma atenuação da abertura descritiva pela explicação psicofisiológica correlata, Wittgenstein denuncia a confusão gramatical que engendra a exclusividade do presente ("a experiência presente é sempre presente", "apenas a experiência presente é real") e a concepção do presente como fluxo incessante (os vividos se escoariam como se sucedem as imagens da película que se desenrola). Nesse afastamento se define, de início, a diferença entre as relações respectivas de Husserl e de Wittgenstein com o núcleo fenomenológico jamesiano, uma vez que Husserl purifica o presente fluente de James, ao passo que Wittgenstein pretende desfazer a confusão da qual esse presente é o produto: a oposição é total a esse respeito. De modo mais geral, em seguida, desenha-se uma divergência entre os tratamentos filosóficos husserliano e wittgensteiniano do tempo, mas também a possível crítica da fenomenologia da consciência do tempo pela terapia gramatical aplicada à idéia de presente fluente.

Pode-se dizer, com efeito, que a questão posta pelo diálogo (reconstruído) entre Husserl e Wittgenstein relativamente ao tempo concerne em última análise ao estatuto que cabe conferir à noção de "fluxo" (Fluss) no seio do projeto de uma descrição da consciência do tempo. Essa questão pode ser formulada nos seguintes termos: há algum sentido em 
falar, mesmo metaforicamente, de um "fluxo" absoluto da consciência que se incumbiria da tarefa de constituir toda forma de temporalidade? Ou ainda: seria o termo "fluxo" apenas um instrumento lingüístico imperfeito para descrever a vida absoluta da consciência ou, pelo contrário, seria ele próprio quem engendraria a idéia de um fluxo absoluto da consciência? Enfim, deve ele ser ultrapassado em direção a um fluxo absoluto que existe independentemente dele ou, pelo contrário, essa última idéia não seria mais que o produto de uma incompreensão da gramática de nossa linguagem (e, em particular, da gramática da palavra “fluxo")? É o próprio projeto de uma fenomenologia da consciência do tempo, destinada a exibir os fenômenos constitutivos do tempo, que se encontra assim posta em causa. A fenomenologia pode ela de direito se livrar dos termos que remetem ao constituído, termos que ela utiliza de forma metafórica - como o "escoamento" (Ablauf) e o "recuo" (Zurückschiebung) no passado?

Wittgenstein afasta-se de sua tentação de 1929 (que o aparentava a Husserl) precisamente ao rejeitar a idéia de um fluxo cujo caráter absoluto proibiria que se possa dizê-lo ${ }^{133}$. Bem depressa, a razão que suscita a tentação de proferir o dictum "Alles fliesst" não é mais, a seu ver, do que um erro de linguagem e a utilização do conceito de fluxo por essedictum, uma utilização metafísica: "quando enunciamos os enigmas que nos são postos pela imprecisão geral da experiência sensível e pelo fluxo de todos os fenômenos, empregamos mal as palavras "fluxo" e "impreciso", de um modo tipicamente metafísico, isto é, sem antítese; ao passo que em seu uso correto e quotidiano, impreciso se opõe a claro, fluxo a estabilidade, inexatidão a exatidão, e problema a solução" (WITTGENSTEIN, 1996, p. 94-95).Aos olhos de Wittgenstein, o emprego absoluto de "fluxo" retirathe todo e qualquer sentido.Assim, a pretensa experiência do escoamento incessante da vida da consciência, quer se trate de sua forma bruta imediata ou de uma forma elaborada como aquela que é proposta pela redução fenomenológica com a apreensão do fluxo absoluto da consciência, representa na verdade um "sentimento"134 (Gefühl) propriamente filosófico, sentido em certas circunstâncias muito particulares ${ }^{135}$. Wittgenstein substitui, portanto, a experiência primordial do escoamento absoluto da vida da consciência pela impressão que operam sobre nós a linguagem e algumas incompreensões a seu respeito ${ }^{136}$. Se Husserl procura depurar a análise psicológica de James, que ele integra, portanto, à sua teoria, Wittgenstein, de seu lado, traça uma linha de demarcação bem nítida entre a lógica que rege e dá significação aos termos de nossa 
86

linguagem e os efeitos psicológicos (os "sentimentos") que a linguagem engendra em nós. $\mathrm{O}$ sentimento do fluxo da consciência está entre esses últimos. A noção de "fluxo" não é portanto um meio indireto e privilegiado de voltar à vida da consciência constitutiva de toda temporalidade, mas um termo de nossa linguagem como outro qualquer ${ }^{137}$, que cabe reconduzir de seu uso metafísico para seu uso ordinário. Em outros termos, "fluxo" só tem sentido quando designa processos temporais ou, de forma metafórica, o próprio tempo. Mas, nesse último caso, precisamente, não nomeia nada, notadamente não um "super fluxo" constitutivo do tempo. No fundo, Para Wittgenstein, Husserl caiu na armadilha de uma metáfora ${ }^{138}$.

\footnotetext{
1 Publicado originariamente em Alter, $\mathrm{n}^{\mathrm{o}} 11$; agradecemos à revista Altera permissão da publicação dessa tradução (nota do ed.). Tradução: Bento de Almeida Prado Neto.

2 Podemos nos reportar em particular ao seguintes estudos: Wilshire, 1968; Edie, 1987; Benoist, artigo inédito.

3 "Se nos voltamos para outros pesquisadores, os problemas fundamentais que foram indicados relativamente a uma fenomenologia da percepção, da representação imaginária, da lembrança e do tempo foram decerto enfrentados repetidas vezes, tanto quanto eu possa julgar, mas de modo algum foram solucionados. Encontram-se algumas intuições aparentadas às minhas, ao que parece, em Stout e Hodgson (abstração feita de James, que ainda estudo e do qual recebi uma forte impulsão)" F I 9/ 4a-b, citado por R. Boehm em sua introdução ao volume X das Husserliana (Hua), (HUSSERL, 1966, p. XVI).

4 Quanto a essa questão, ver: Cobb-Stevens, 1998; Edie, 1987, p. 5, 28, 30, 42;Wilshire, 1968, p. 100-101, 206.

5 Fenomenologia que se poderia qualificar de "hilética" no sentido específico que indico a seguir (Cf. HUSSERL, 1964, § 8. p. 37; Suplemento III, p. 141).Ver, a esse respeito, as observações de G. Granel em Le sens du temps et de la perception dans la phénoménologie d'E. Husserl (GRANEL, 1968, p. 22-38 notadamente).

6iVer igualmente Husserl, 1964, Suplemento III, p. 141.

7 Cf. Husserl, 1964, § 42, p. 136: “Uma percepção é a consciência de um objeto. Mas é também, enquanto consciência, algo presente de forma imanente".

8 Husserl, 1964, Suplemento III, p. 140.

9 Cf. Cobb-Stevens ,1998, p. 45.

10 Husserl, 1964, § 1, p. 11-12.

${ }^{11}$ Ver, em particular, Husserl, 1950, § 86.

12 Husserl, 1950, § 81, p. 274.

13 Que cabe, no entanto, não confundir com a "fenomenologia hylética" (HUSSERL, 1964, $\S 85$, p. 294) esboçada nas Ideen, uma vez que a hyle das Lições revela a vida própria de sua
} 
constituição, que falta à hyle da fenomenologia transcendental.Ver $\S 85$, p. 288 , no que diz respeito à definição dos "conteúdos primários" (ou) "conteúdos de sensação" no nível da fenomenologia transcendental.

14 Husserl, 1964, § 1, Nota de Husserl, p. 11.

15 Husserl, 1964, § 12.

16 Husserl, 1964, § 6, p. 30 e Husserl, 1957, § 107 c, p. 379.

17 Husserl escreve logo depois:"na 'interioridade imanente' do ego tampouco há antecipadamente objetos”(p. 380). Cf. igualmente: Husserl, 1964, § 37, p. 100.

18 É então que Husserl deixa verdadeiramente o nível kantiano de sua análise (HUSSERL, 1998).

19 James, 1981, IX, p. 227. James designa pelo termo "feeling" "todos os estados de consciência enquanto tais, independentemente de sua qualidade particular ou de sua função cognitiva" (VII, p. 185).

20 Cf. as observações críticas de G. Granel (GRANEL, 1968, p. 35 notadamente).

21 Cf. James, 1981, XV. Cf. IX, p. 224-227 quanto ao modelo heracliteano da consciência.

22 Cf., entre outros: Husserl, 1964, § 9, p. 41:“die Ablaufsmodi”.

23 Husserl, 1964, § 2, p. 14:“die primitiven Gestaltungen des Zeitbewusstseins”.

24 "Dauer der Empfindung und Empfindung der Dauer ist zweierlei. Und ebenso ist es bei der Sukzession. Sukzession von Empfindungen und Empfindung der Sukzession ist nicht dasselbe" (HUSSERL, 1966, p. 12). "A succession of feelings, in and for itself, is not a feeling of succession” (JAMES, 1981, XV, p. 591). H. Dussort assinala esse caráter literal na nota 1, p. 21 de sua tradução.

25 "an additional fact requiring its own special elucidation".

26 Acerca da anterioridade lógica da duração sobre a sucessão e do debate clássico relativo a essa questão, cf. James, 1981, XV, p. 574, nota 4.

27 O próprio Russell faz sua essa análise de James, em particular em sua Theory of Knowledge (RUSSELL, 1992, part I, cap.VI).

28 James, 1981, XV, p. 600.

29 James, 1981, p. 570, 594. Nem no capítulo XV, nem no capítulo XVI (consagrado à memória e apoiado nas análises do sentimento do passado contidas no capítulo sobre o tempo) James precisa as modalidades dessa derivação.

30 James, 1981, p. 570

${ }^{31}$ Abertura que S. H. Hodgson também realiza em sua Philosophy of Reflection, obra que, como vimos acima, Husserl conhecia. James cita longamente esse autor no capítulo XV.

32 Husserl, 1964, § 1, p. 9, § 11, p. 46.

33 Husserl, 1964, § 31, p. 88, onde Husserl distingue, no seio da impressão, (a) a impressão originária, i.e., o agora pontual e (b) o contínuo das modificações próprio à lembrança primária (Cf. COBB-STEVENS, 1998, p. 44-46).

${ }^{34}$ A análise do tempo que Husserl ataca foi sustentada por Brentano nos anos 1873-95. Para 
88

uma posição brentaniana ulterior e diferente, cf. Brentano, 1976.Ver igualmente os comentários de H. Dussort, p. 189-192 de sua tradução.

35 Husserl, 1964, § 4, p. 22.

36 "Em conseqüência de sua teoria, Brentano acaba por negar a existência da percepção da sucessão e da mudança. Cremos ouvir uma melodia e, portanto, ouvir também aquilo que acaba de passar, mas isso é apenas uma aparência (Schein) que provém da vivacidade da associação originária" (HUSSERL, 1964, § 3, p. 22).

37 Husserl, 1964, § 6, p. 25. Cf., Cobb-Stevens, 1998, p. 44.

38 Cf. Manuscrito 105, p. 116; Manuscrito 107, p. 1-2, 159, 222. Os manuscritos (Ms) de Wittgenstein são citados in:Wittgenstein, 1998. A paginação indicada é a dessa edição.

${ }^{39}$ Ver as observações de D. Stern a esse respeito (STERN, 1991, p. 589).

40 Wittgenstein, Ms. 108, p. 1; Ms 111, p. 4; Moore, 1997, p. 124.

41 Cf. Wittgenstein, Ms. 111, p. 4-5; Big Typescript (Ts 213), § 102, p. 494-495.

${ }^{42}$ Ver igualmente p. 159.

43 O Big Typescript colocará uma versão revisada desse último texto sob o título "A experiência do momento presente é a verdadeira realidade (die eigentliche Realität)" ( $§ 102$, p. 494 - a versão revisada encontra-se na p. 496), o que confirma a legitimidade da aproximação da "consideração do presente como a única coisa real" (WITTGENSTEIN, Ms 107, p. 1) com o "fenômeno presente" que a fenomenologia se dá como objeto de descrição (WITTGENSTEIN, Ms 105, p. 116).

44 Wittgenstein, Ms 105, p. 5. Wittgenstein fala de uma “Grammatik der Beschreibung”.Ver igualmente Wittgenstein, 1991, p.33.

45 "Só podemos chegar a uma análise correta por meio daquilo que poderíamos chamar de uma investigação lógica dos próprios fenômenos, i.e., num certo sentido a posteriori,e não formulando conjeturas relativas a possibilidades a priori."(WITTGENSTEIN, 1966, p. 32).

46 Cf. em particular Wittgenstein, Ms 105, p. 108-110, acerca dessa tentativa de descrição fenomenológica.Ver, a esse respeito, os comentários de W.Kienzler (KIENZLER, 1997, p. 118 e ss).

47 Cf.igualmente p. 205.

48 Nessa época, porque depois a analogia cinematográfica será investida de um sentido diferente por Wittgenstein.

49 Para uma utilização anterior da analogia cinematográfica nesse sentido, cf.Wittgenstein, Ms 105, p. 84-86. Acerca do caráter físico da linguagem, cf. Wittgenstein, Ms 105, p. 114.

50 "A linguagem fenomenológica descreve exatamente a mesma coisa que a linguagem ordinária, fisicalista. Deve apenas limitar-seàquilo que é verificável'(WITTGENSTEIN, Ms 105, p. 108; grifo meu).

51 Cf. Wittgenstein, Ms 105, p. 112;Wittgenstein, 1984a, § 68 b, p. 97;Wittgenstein, Ms 113, p. 123v; Wittgenstein, BT, $\S 101$, p. 492.

52 Cf. Stern, 1995, II, cap. 6, p. 160.

53 Marion, 1998, 5.2, p. 139, nota 35. 
54 Acerca da primeira hipótese, podemos observar que se Wittgenstein remete efetivamente essa concepção ao pensador efésio ao recorrer ao dictum "Alles fliesst", resta que a versão da tese heracliteana apresentada por Platão nos diálogos que Wittgenstein leu (cf. notadamente Crátilo, 402b, 411c, 439c e Teeteto, 181d-183c) desdobra antes de tudo uma crítica da substância totalmente estranha ao pensamento wittgensteiniano. O fluxo de que Wittgenstein fala é muito antes um "fluxo do fenômeno (Fluss der Erscheinung)" (WITTGENSTEIN, Ms 108, p. 32; WITTGENSTEIN, 1984a, §52 ab), isto é, precisamente esse "perpétuo fluxo heracliteano dos fenômenos" do qual Husserl fala igualmente (HUSSERL, 1970, III, p. 72). A segunda hipótese avança o nome de Russell, sob o pretexto de que o conceito de "specious present" aparece nas análises de Wittgenstein (Ms 105, p. 114;, 1984a, § 69 a; Ms 113, p. 123v; BT, § 102, p. 495): ele proviria da leitura da Theory of Knowledge de 1913, na qual Russel o utiliza (RUSSELL, 1992, part I, cap. VI, p. 68-69). Mas uma observação se opõe à adoção dessa solução: Russell não convoca o "specious present" sem fazer imediatamente referência à fonte jamesiana desse conceito (RUSSELL, 1992, p. 72) - ele procede de mesmo modo em The Analysis of Mind (1921), (RUSSELL, 1997), Lecture IX, p. 174. Wittgenstein não podia portanto ignorar a verdadeira origem jamesiana deste conceito.

55 Em particular os capítulos IX e XV.

56 James, 1981, IX, p. 227: "and that whatever was true of the river of life, of the river of elementary feeling, it would certainly be true to say, like Heraclitus, that we never descend twice into the same stream".

57 James, 1981, XV, p. 593:"Its content is in a constant flux".

58 "Where is it, this present? It has melted in our grasp, fled ere we could touch it, gone in the instant of becoming". Sem dúvida, sob esse aspecto, a análise de James estende sua influência até em Bergson. Com efeito, este último opera uma distinção muito próxima (a do "presente ideal" e do "presente concreto") que ele ilustra, exatamente como James, com o célebre verso de Boileau, cf. Bergson, 1959, p.280.

59 James, 1981, IX, p. 233.

60 Husserl, 1964, § 36:“Zeitkonstituierende Fluss als absolute Subjektivität”.

61 5.63.Além disso, para o Wittgenstein de 1929, bem como para o do Tractatus:"Aquilo que o solipsismo [instantaneísta, doravante] quer significar é inteiramente correto, apenas isso não pode ser dito, mas se mostra" (5.62).

62 Cf. Husserl, 1984, § 31-32.Ver o comentário de R. Bernet sobre esse ponto (BER NET, 1983,p. 186-187).

63 Cf. igualmente Wittgenstein, Ms 105, p. 286;Wittgenstein, 1984a, § 75, p. 104.

$64 \mathrm{Cf}$. minhas observações da seção 1.1 .

65 É a idéia de que a sucessão das percepções não basta para dar conta descritivamente desse "fato suplementar" da percepção da sucessão.A esse respeito, cabe ler em paralelo James, 1981 (VII, p. 194-195; XV, p. 591).

66 Wittgenstein, 1984a, § 54.Ver igualmente Wittgenstein, 1991, p. 60-61. Husserl, aliás, não está tão distante do argumento lógico invocado por Wittgenstein, quando ele escreve: "Mas não há aqui algo de extremamente surpreendente? Será que se pode falar em sentido próprio de uma mudança ali onde, no entanto, é impensável uma ausência de mudança, uma duração que fosse preenchida sem que nela houvesse mudança? É impossível colocar uma ausência de mudança ao lado do fluxo contínuo das fases de aparição" (HUSSERL, 1964, SuplementoVI, 
p. 150-151; grifo meu).

67 Cf. Russell, 1997, IX, p. 173 e ss., onde Russell afirma explicitamente tratar do problema psicológico da memória.

68 Cf. Husserl, 1964, § 5, p. 24;Wittgenstein, 1984a, § 54 d.

69 Cf. supra,1,3.

70 Cf. Wittgenstein, 1988, p. 90; Wittgenstein, 1992, p. 39-40;Wittgenstein, Ms 156 a, p. 11 12; Datiloscrito 219, p. 18.

${ }^{71}$ Ver igualmente Russell, 1927, cap. 1.

72 Essa distinção entre a lembrança (errônea) e a realidade não põe problema, o que o próprio Husserl reconhece:"Assim, não sustentamos como uma evidência que, quando temos uma retenção de $A$ (supondo que $A$ é um objeto transcendente), $A$ deve tê-la precedido, mas sim que $A$ deve ter sido percebido"(HUSSERL, 1964, § 13, p. 49; grifo meu).

73 A possibilidade dessa hipótese deve ser compreendida à luz da definição russelliana do instante como classe de acontecimentos simultâneos (RUSSELL, 2002, Quarta conferência, p. 150-155): se os acontecimentos passados são ilusórios, então o próprio passado também o é, uma vez que todo instante passado se define como uma classe de acontecimentos passados simultâneos.

74 Brentano sustenta, com efeito, que a lembrança imediata é uma imagem produzida pela imaginação e não uma intuição do passado, uma vez que, com o observa Husserl, isso eqüivale a considerar que a percepção do recém-passado é apenas uma "aparência" (Schein).

75 A mesma idéia encontra-se igualmente expressa na observação de Wittgenstein de que o presente exclusivo da experiência imediata não pode ser chamado propriamente de "presente" (o adjetivo é qualificado de "supérfluo", überflüssig, por Wittgenstein) uma vez que não se opõe a nenhum passado nem a nenhum futuro (WITTGENSTEIN, 1984a, $§ 54$ f, p. 85).

76 Cf., por exemplo, Über Gewissheit, § 71. Portanto, a crítica endereçada por Moore a Wittgenstein em suas notas de curso (MOO RE, 1997, p. 136-137) realmente erra seu alvo. Com efeito, é precisamente a idéia russelliana de que haveria um sentido em "afirmar que é logicamente possivel que o mundo não tenha existido" (MOO RE, 1997, p. 137) que Wittgenstein rejeita. Na medida em que essa possibilidade repousa sobre a idéia da pertinência de uma dúvida generalizada acerca da lembrança, ela não é defensável para Wittgenstein.

77 Cf. a afirmação, extremamente clara, de Russell: "There is no logically necessary connection between events at different times" (RUSSELL, 1997, p. 159).

78 Husserl, 1964, § 5, p. 24:"real ist nur die Bestimmung des Jetzt".

${ }^{79}$ Wittgenstein, 1984a, § 54 d, p. 85:“"nur die Erfahrung des gegenwärtigen Augenblicks hat Realität”.

80 "Hence the ocurrences which are called knowledge of the past are logically independent of the past; they are wholly analysable into present contents, which might, theoretically, be just what they are even if no past had existed" (Russell, 1997, p. 160; grifo meu).

81 Husserl conclui assim sua apresentação crítica da análise brentaniana:"Seria preciso portanto que o passado, na medida em que ele cai na esfera da intuição originária do tempo, fosse também presente. Seria preciso, no mesmo sentido, que o momento temporal 'passado' fosse um momento presente do vivido, como o momento ‘vermelho' que vivemos atualmente - o 
que é no entanto um contra-senso manifesto. (...) Na verdade, todo o domínio das associações originárias é um vivido presente e real" (HUSSERL, 1964, § 6, p. 28-29).

82 'Seria preciso, no mesmo sentido, que o momento temporal 'passado' fosse um momento presente do vivido" (HUSSERL, 1964, § 6, p. 28-29).

83 Cf. Russell, 1997, IX, p. 162.

84 Cf. Russell, 1997, p. 175; Husserl, 1964, § 1-3 (sobre o papel da imaginação na psicologia brentaniana do tempo).

85 "the sensation which an image is supposed to copy is in the past, when the image exists, and can therefore only be known by memory, while, on the other hand, memory of past sensations seems only possible by means of present images. How, then, are we to find any way of comparing the present image and the past sensation? (...) it is the very possibility of comparison that is hard to understand".Ver igualmente p. 164.

86 "the ocurrences which are called knowledge of the past are logically independent of the past: they are wholly analysable into present contents".

87 O termo "reell" em Husserl designa os conteúdos do ato de consciência que existem verdadeiramente, por oposição ao objeto intencional. Esse termo caracterizará assim o primeiro dos dois sentidos de "imanência" distinguidos por Husserl em seu curso $A$ idéia da fenomenologia, Husserl, 1970, II, p. 59.

88 Cf. Husserl, 1964, § 12, p. 47-48. Husserl evoluiu acerca desse ponto. Como o atestam certos textos (cf., em particular, Husserl, 1966, B, n 48, p. 318-319; $\mathrm{n}^{\circ} 49$, p. 324), ele próprio sustentou a "Repräsentationstheorie" segundo a qual um conteúdo real presente, mediante um ato de interpretação, ocupa a função de representante do acontecimento rememorado. A esse respeito, Bernet, 1983, p. 189; Cobb-Stevens, 1998, p. 49-50.

89 Sustentar o contrário eqüivale em suma a confundir a audição de uma melodia com a de um acorde, ou de uma cacofonia (HUSSERL, 1964, § 3, p. 19-20, 22; § 7, p. 36-37; § 12, p. 46-47).

90 "Wenn ich sage 'Vor einer halben Stunde war er da' - nämlich aus der Erinnerung - so ist das nicht die Beschreibung eines gegenwärtigen Erlebnisses".Ver igualmente Wittgenstein, 1984a, § 56, p.86-87.

91 Cf. "erschliessen" in: WITTGENSTEIN 1984d, § 220 \& "schliessen" in: WITTGENSTEIN 1984d, § 903.

92 Husserl, 1964, § 16, p. 54: "Uma objetividade do gênero de uma melodia não pode ser 'percebida', dada ela própria originariamente, a não ser sob essa forma"; p. 55: "Os objetos temporais, isso pertence à sua essência, desdobram sua matéria por um lapso de tempo,e tais objetos só podem constituir-se em atos que constituem precisamente as diferenças do tempo".

93 “eine sekundare Art der Erfahrung, im Vergleich zur Erfahrung des Gegenwärtigen”.

94 “A lembrança e, por conseguinte, a retenção não são uma consciência de imagem, mas algo totalmente diferente" (HUSSERL, 1964, § 13, p. 50). "Es ist ja klar, dass die Ausdrucksweise vom Gedächtnis als einem Bild, nur ein Gleichnis ist, genau so wie die Ausdrucksweise, die die Vorstellungen 'Bilder der Gegenstände in unserem Geiste' (oder dergleichen) nennt" (WITTGENSTEIN, 1984a, § 49, p. 82). Cf. igualmente: Husserl, 1998, p. 56 (sobre a diferença entre "Erinnerung" e "Abbildung").

95 "É pôr tudo de ponta cabeça, escreve Husserl, argumentar: como posso eu ter, no agora, 


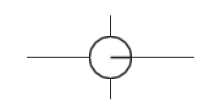

\section{2}

conhecimento de um não-agora, uma vez que não posso comparar o não-agora, que já não é mais, com o agora (isto é, com a imagem lembrança que está no agora). Como se pertencesse à essência da lembrança que uma imagem (Bild), que temos no agora, fosse posta no lugar de uma outra coisa a ela semelhante e que eu devesse e pudesse fazer uma comparação, como no caso de uma apresentação por imagem”. Por conseguinte:"Uma comparação daquilo que não é mais percebido, mas apenas retencionalmente consciente, com algo fora dele, não tem absolutamente nenhum sentido" (HUSSERL, 1964, § 13, p. 49-50).Ver igualmente § 28, p. 78-79, onde Husserl distingue a rememoração da consciência de imagem. Wittgenstein, do mesmo modo, recusa atribuir um sentido à idéia de uma comparação da lembrança com a experiência passada da qual ela é a lembrança:"“Caracteriza-se a lembrança como uma imagem (Bild). No entanto, eu posso comparar a imagem com o original, mas não a lembrança. Os vividos do passado não são como os objetos no quarto ao lado, objetos que, pelo momento, não vejo, mas que posso ir ver. Pois posso eu ir ao passado?" (WITTGENSTEIN, 1991, p. 17).Ver igualmente, acerca dessa mesma idéia:Wittgenstein, 1997, p. 160-161; Wittgenstein, 1984a, § 49.

96 Cf. Wittgenstein, 1984a, § 49, p. 81.

97 Husserl, 1964, § 16, p. 56.

98 Wittgenstein, 1999, p. 182, sessão do 06.05.36: “'Only the present is real' is not, in one sense, just equivalent to 'the present is the present'. It is more like putting the present on a pedestal, like crowning it - ('real' in a laudatory sense)."

99 Cf., em particular: Budd, 1989; Glock, 1996 ,"Memory"; Hacker, 1996 ,"Memory and recognition”, p. 480 e ss.; Malcolm, 1977; Schulte, 1987, cap. 7,“Erinnerung”.

100 Cf., sobretudo:Wittgenstein, 1984a, § 49, p. 81-82, retomado literalmente em BT, $\S 105$, p. $517-518$

101 Uma vez que a distinção dos dois sentidos da memória, que data do início dos anos 1930, se reencontra nos textos dos anos 1940: cf., em particular, Wittgenstein, 1985, $§ 837$ (a lembrança como "das Kriterium desVergangenen").

102 Cf. Husserl, 1964, § 16, p. 54-55.

103 James, 1981, I, p. 15 (grifo meu): "Psychology is the Science of Mental Life, both of its phenomena and of their conditions".

104 O mesmo ocorre com a análise da memória, uma vez que a segunda e a terceira seções do capítulo XVI tratam respectivamente do "fenômeno" e das "causas" da lembrança secundária.

105 James, 1981, XV, p. 593-4, 598.

106 Cf. Husserl, 1964, § 12, p. 46-47, onde Husserl recusa assimilar a intuição do passado própria à lembrança imediata a uma "ressonância", isto é, a um momento real (reell) da consciência.

107 James reconhece, aliás, em termos explícitos, que presente e passado imediato devem estar simultaneamente na consciência para poderem ser percebidos como sucessivos. (JAMES, 1981, XV, p.592-593).

108 Cf., a esse respeito, as análises de J. Edie (EDIE, 1987, p. 42).

109 James, 1981, XVI, p. 605, onde James delineia uma analogia entre a relação do tempo intuitivo com o tempo concebido e a da cena de teatro (espaço real) com o cenário que o cerca (espaço fictício).

110 Cf. James, 1981, X, p. 323 :"It may feel its own immediate existence (...) but nothing can 
be known about it till it be dead and gone".

111 Husserl, 1964, § 1, p. 11-2; § 36, p. 99:“Assim, escreve ele, a sensação (die Empfindung), se entendemos com isso a consciência (e não o vermelho imanente que dura, o tom, etc., isto é aquilo que é sentido [das Empfundene]), assim como a retenção, a rememoração, a percepção etc. não é nada de temporal (unzeitlich), isto é, nada que se encontraria no tempo imanente" (HUSSERL, 1966, $\mathrm{N}^{\circ}$ 50, p. 333-334).Ver, igualmente, 1964, § 39, p. 109, onde Husserl fala da "inserção quase temporal das fases do fluxo" (grifo meu).

12 Husserl, 1964, § 39, p. 105 (onde Husserl enuncia a dificuldade); p. 107-109 (para a distinção e a "unidade indissolúvel" das intencionalidades retencionais "longitudinal" e "transversal").

13 Waismann, 1976, X, 5, p. 302, que apresenta uma versão retocada, se tanto, do texto de Wittgenstein, 1997, p. 157 e ss.

14 Wittgenstein, 1984a, § 52 a, p. 83.

115 Wittgenstein, Ms 107,p. 2.

116 Cf. Wittgenstein, Ms 108, p. 33-34;Wittgenstein, 1984a, § 49; BT, § 105, p. 517.

117 Para outras origens, cf. (1) a aplicação do conceito de exatidão à experiência imediata: Wittgenstein, 1997, p. 160; BT, 96, p. 448;Wittgenstein, 1984b, § 435-436; (2) a ausência de critério para decidir se uma impressão (privada) é idêntica àquelas que a precedem ou se as impressões são o tempo todo diferentes e formam a esse título um fluxo permanente: Wittgenstein, 1999, XII, Sessão do 6 de maio de 1936, p. 178 e ss; (3) a confusão do advérbio "agora" com um nome de instante: Wittgenstein, 1999, p. 182; Wittgenstein, 1969, § 56, p. 108-109.

118 Cf. a "Zurückschiebung” sofrida por toda nova impressão originária segundo as Lições.

119 die "Übertragung des Zeitbegriffs der physikalischen Zeit auf den Verlauf der unmittelbaren Erlebnisse".

120 Wittgenstein, 1984a, § 49, p. 81.

121 Wittgenstein, Ms 108, p. 27;Wittgenstein, 1984a, § 52 c, p. 84; BT, § 101, p. 487.

122 Wittgenstein, 1991,pp. 7 \& 23.Wittgenstein, 1984c, § 131e,p. 182; Wittgenstein, 1984b, § 649.

123 Wittgenstein, BT, § 101, p. 487.

124 Acerca da aplicação do qualificativo "presente" à experiência imediata, Wittgenstein escreve:"ele não pode significar presente por oposição a passado e futuro. - Entende-se necessariamente algo diferente por essa palavra, algo que não está em um espaço, mas que é ele próprio um espaço. Isto é, não algo que limita outra coisa (e, por conseguinte, delimitável por outra coisa). Enfim, algo que a linguagem não pode distinguir"(Wittgenstein, 1984a, § $54 \mathrm{f}, \mathrm{p}$. 85). Acerca da experiência enquanto absoluta, cf.Wittgenstein, 1988, p. 69; BT, § 107, p. 528; Ts 219, p. 20; Wittgenstein, 1997, p. 163 e ss.

125 “Evidentemente, escreve Wittgenstein, a palavra 'presente’ também está aqui fora de lugar. Pois em que medida se pode dizer da realidade [i.e., fenomenal] que ela é presente? Apenas se a inserimos de novo em um tempo que lhe é alheio [i.e., o tempo físico]. Em si e para si ela não é presente" (Wittgenstein, 1984a, § 75g, p. 104). A mesma idéia é expressa pelo seguinte texto: 'Mas, justamente, aqui a palavra 'presente' não tem nenhum sentido, pois não deve significar presente por oposição a passado, mas gostaríamos aqui verdadeiramente de falar de 
94

uma experiência presente presente (einergegenwärtigen gegenwärtigen Erfahrung)"(Wittgenstein, Ts 219, p. 19).

126 Perigo que ele não cessou de denunciar, cf. notadamente Ms 107, p. 160 \& BT, § 94, p. 438.

127 No sentido indicado mais acima: Cf. Husserl, 1964, § 42, p. 116.

128 Ver igualmente Wittgenstein, 1984a § 51, p. 83; Ms 110, p. $179 \&$ 182; Ms 111, p. 6; Wittgenstein, 1999, p. 209.

129 Ver, entre outros: Wittgenstein, 1984a, § 54 d, p. 85; BT, § 102, p. 497-498;Ts 219, p. 18; Wittgenstein, 1999, p. 155, 179, 181-182.

130 Cf.Wittgenstein, 1992, p. 39, onde Wittgenstein atribui o solipsismo instantaneísta a James (cf. JAMES, 1981, IX, p. 233).

131 Wittgenstein, 1999, p. 182.

132 Tradução modificada:"We have the false view that the present is being destroyed". Eis por que Wittgenstein estende o uso salvador da analogia cinematográfica, de início reservado à experiência imediata, ao próprio tempo: "A maior parte dos enigmas que parecem nos ser postos pela essência do tempo, escreve Wittgenstein, nós os podemos compreender ao considerarmos a analogia que se encontra, de uma forma ou de outra, na origem das diferentes concepções errôneas: trata-se, de um lado, do processo de desenrolamento de uma película no interior do aparelho de projeção e, de outro, do processo na tela" (WITTGENSTEIN, Ms 112 , p. 128r; BT, § 105, p. 519). E ele escreve alhures:"A analogia do fluxo (Fluss)/ do escoamento (Fliessen)/ do tempo é enganosa, é claro, e se nos agarrarmos a ela, ela irá nos conduzir/ colocar/ fazer cair inevitavelmente em dificuldades." (Ms 110, p. 39).

133 Cf. a seção 1,3 deste estudo.Ver a evolução que se opera ao longo da série: Ms 108, p. 1; Wittgenstein, 1984a, § 54; Ms 114, p. 21r;BT, § 91, p. 427.

134 Cf. Wittgenstein, BT, § 87, p. 410; § 91, p. 428.

135 Cf. Wittgenstein, 1984a, § 52 ab, p. 83;Wittgenstein, 1997, p. 161.

136 Acerca da crítica de uma experiência do fluxo do tempo, cf.Wittgenstein, Ms 116, p. 230231,: “'Die Zeit ist überall im gamzen Raum.' Um zu zeigen, dass es so ist, stelle ich mich irgendwo hin \& mache eine Geste, die das Verfliessen andeutet. Und sage zum Andern: Du siehst, die Zeit verfliesst. - 'Und ist es nicht, als sähe, oder fühlte, ich es wirklich? Ist das nicht merkwürdig! Was nehme ich denn wahr? Etwa eine Handbewegung \& was sonst gerade vorgeht, \& doch möchte ich sagen, ich sei mir jetzt desVerlaufs der Zeit bewusst. Ich bin mir eines Bildes bewusst, das die Worte 'Verfliessen der Zeit' herauf bringen.'Ver igualmente Ms 109, p. 71: "Es ist offenbar, dass der Charakter des zeitlichen in der Bedeutung der Wörter 'früher', 'später' etc liegt. In der Reihe die so gebildet wird. Und es frägt sich ob wir jedes Erlebnis als Glied der Reihe erleben - Auch die Dauer scheint mir nicht in jedes Erlebnis unmittelbar hineinzuspielen" (grifo meu).

137 A noção de "fluxo", portanto, não "pré-forma" menos a experiência do que o par "sujeito-objeto", cf. Lapoujade, 1997, p. 30.

138 De modo mais preciso, é uma confusão gramatical (cf. 3,2) que produz a idéia de um fluxo da consciência. E essa idéia leva a tomar a expressão metafórica do "fluxo do tempo" no sentido literal de um fluxo absoluto da consciência constitutiva do tempo. 


\section{Referências Bibliográficas}

BENO IST, J. Phénoménologie ou pragmatisme? (artigo inédito).

BERGSON, H. Matièreet Mémoire (éd. du Centenaire). Paris: PUF, 1959.

BER NET, R., "La présence du passé dans l'analyse husserlienne de la conscience du temps". In: Revue de Métaphysique et de Morale, nº 2, 1983.

BRETANO, F.Philosophische Untersuchungen zu Raum, Zeit und Kontinuum, Zweiter Teil. Hamburgo: Felix Meiner, 1976.

BUDD, M. Wittgenstein's Philosophy of Psychology. Londres: Routledge, 1989.

CAVELL, S. “The Availibility of Wittgenstein's Later Philosophy”. In: Ludwig Wittgenstein - Critical Assessments (St. Shanker ed.), vol. II.

Londres: Croom Helm, 1986.

COBB-STEVENS, R. "James and Husserl: Time-Consciousness and the Intentionality of Presence and Absence". In: Self-Awareness, Temporality and Alterity (Dan Zahavi ed.). Dordrecht /Boston /Londres: Kluwer, 1998.

EDIE, J. M. W. James and Phenomenology. Indianapolis: Indiana University Press, 1987.

GRANEL, G. Le sens du temps et de la perception dans la phénoménologie d'E. Husserl. Paris: Gallimard, 1968.

GLOCK, G. A Wittgenstein Dictionary. Oxford: Blackwell, 1996.

HACKER, P.M.S. Wittgenstein - Mind and Will. Oxford: Blackwell, 1996.

HUSSERL, E. Zur Phänomenologie des inneren Zeitbewusstseins (18931917), Husserliana X. Haag: M. Nijhoff, 1966. . Leçons pour une phénoménologie de la conscience intime du temps, tradução de H. Dussort. Paris: PUF, 1964. . Idées directrices pour une phénoménologie et une philosophie phénoménologique pure I.Paris: Gallimard, 1950. . Logique formelle et logique transcendantale.Paris: PUF, 1957. . Analysen zur passiven Synthesis (Hua XI) [Edição francesa: De la synthèse passive, Grenoble, Jérôme Millon, 1998]. 
96

. L'idée de la phénoménologie.Paris: PUF, 1970.

JAMES, W. The Principles of Psychology. Cambridge/Londres: Harvard University Press, 1981.

LAPOUJADE, D. W. James. Empirisme et Pragmatisme. Paris: PUF, 1997.

KIENZLER, W. Wittgenstein's Wende zu seiner Spätsphilosophie.

Frankfurt: Suhrkamp, 1997.

MALCOLM, N. Memory and Mind. New York: Cornell University

Press, 1977.

MARION, M. Wittgenstein, Finitism and the Foundations of Mathematics.

Oxford: Clarendon Press, 1998.

MOO RE, G. E. Les Cours de Wittgenstein en 1930-33. Mauvezin: TER, 1997.

RUSSELL, B. Theory of Knowledge. Londres: Routledge, 1992.

. The Analysis of Mind. Londres: Routledge, 1997.

Our Knowledge of the External World. [Edição francesa:

Payot, 2002].

An Outline of Philosophy. Londres: George Allen \&

Unwin, 1927.

SCHULTE, J. Erlebnis und Ausdruck - Wittgenstein `s Philosophie der

Psychologie. München: Philosophia Verlag, 1987.

STERN, D. “Heraclitus' and Wittgenstein's River Images: Stepping

Twice Into the Same River”. In: The Monist, v. 74, 1991.

University Press, 1995.

. Wittgenstein on Mind and Language. Oxford: Oxford

WILSHIRE, B. W. James and Phenomenology: a Study of "The Principles of

Psychology”. Bloomington: Indiana University Press, 1968.

WAISMANN, Fr. Logik, Sprache, Philosophie. Stuttgart: Reclam, 1976.

WITTGENSTEIN, L. Wittgenstein's Nachlass - The Bergen Electronic

Edition. Oxford: Oxford University Press, 1998

. Wittgenstein und der Wiener Kreis. [Edição francesa: 
Wittgenstein et le cercle de Vienne. Mauvezin: T.E.R., 1991]. . "Some Remarks on Logical Form". In:Copi \& Beard ed., Essays on Wittgenstein's Tractatus. Londres: Routledge, 1966. . Philosophische Bemerkungen. Frankfurt: Suhrkamp, 1984a. . Les cours de Wittgenstein à Cambridge(1930-32). Mauvezin, T.E.R., 1988. . Philosophische Grammatik.Frankfurt: Suhrkamp, 1984c. . Les cours de Cambridge 1932-35. Mauvezin:T.E.R., 1992. The language of Sense Data. [Edição francesa: Le langage de l' experience privée et des "sense-data". Mauvezin: T.E.R., 1999]. . Philosophische Untersuchungen. Frankfurt: Suhrkamp, 1984b. . Bemerkungen über die Philosophie der Psychologie. Frankfurt: Suhrkamp, 1984d. . Dictées de Wittgenstein à Waismann et pour Schlick, I. Paris: PUF, 1997.

. Letzte Schriften über die Philosophie der Psychologie I. [Edição francesa: Études préparatoires à la seconde partie des Recherches philosophiques. Mauvezin: T.E.R., 1985].

. Brown Book. Oxford: Blackwell, 1969.

Gallimard, 1996]. . Blue Book. [Edição francesa: Cahier bleu.Paris: 